МIНІСТЕРСТВО ОСВІТИ І НАУКИ УКРАЇНИ

Харківський національний економічний університет імені Семена Кузнеця

\author{
А. А. Кудь, М. А. Мащенко, \\ I. С. Пипенко, I. В. Соболева
}

\title{
ПРОГНОЗУВАННЯ ВПЛИВУ ЦИФРОВИХ АКТИВІВ НА СОЦІАЛЬНО-ЕКОНОМІЧНИЙ РОЗВИТОК ПІДПРИЕМСТВА
}

Методичний посібник

Харків

"ХОГОКЗ"

2020 
УДК 338.12.017(072)

DOI $10.26697 / 9786177089093.2020$

П 78

Рекомендовано Вченою радою

факультету економіки і права ХНЕУ ім. С. Кузнеця

(протокол № 6 від 11 березня 2020 року)

\section{Авторський колектив:}

Кудь А. А. (розділ 2), Мащенко М. А. (вступ, розділ 3, висновки), Пипенко I. С. (розділ 1), Соболева I. В. (розділ 3).

\section{Рецензенти:}

Гавкалова Н. Л. - доктор економічних наук, професорка, завідувачка кафедри державного управління, публічного адміністрування та регіональної економіки Харківського національного економічного університету імені Семена Кузнеця.

Марченко О.С. - доктор економічних наук, професорка, професорка кафедри економічної теорії Національного юридичного університету імені Ярослава Мудрого.

\section{П 78 економічний розвиток підприсмства: метод. посіб./Кудь А. А. та ін. Харків: ХОГОКЗ, 2020. 76 с. doi: $10.26697 / 9786177089093.2020$}

У методичному посібнику досліджено явище соціально-економічного розвитку, обгрунтовано особливості соціокультурного контексту, які формують розуміння сутності соціально-економічного розвитку; визначено вплив сучасних інформаційних технологій, які істотно змінюють моделі та способи ведення бізнесу. Досліджено сутність поняття “цифровий актив” на підставі етимологічного аналізу та прогнозування соціально-економічного розвитку від впливу цифрового активу в умовах антимонополізації економіки. Визначено принципи побудови антимонопольного регулювання економіки в умовах цифровізації економіки. Це дослідження погоджено та затверджено як науководослідна робота ХНЕУ ім. С. Кузнеця (договір № 649-56 від 13.12.2019 р.).

Методичний посібник адресується фахівцям у сфері інформаційної та цифрової економіки, юристам, фінансовим організаціям, представникам бізнес-спільнот.

$$
\text { УДК 338.12.017(072) }
$$

Видання розміщується в міжнародних репозиторіях та базах даних: Crossref, Google Scholar, Scilit та ін.

(C) ХНЕУ ім. С. Кузнеця, 2020

ISBN 978-617-7089-09-3 С Кудь А. А., Мащенко М. А.,

Пипенко I. С., Соболева I. В., 2020

(C) ХОГОКЗ, оформлення, 2020 


\section{MICT}

Перелік скорочень та умовних позначень 4

Вступ

Розділ 1. Теоретичні основи соціально-економічного 6 розвитку в сучасних умовах

Розділ 2. Комплекс базових понять феномену 26 “цифровий актив"

Розділ 3. Вплив цифрових активів на соціальноекономічний розвиток та роль прогнозування в умовах антимонополізації економіки

Висновки

Лiтература

69 


\section{Перелік скорочень та умовних позначень}

ВВП - Валовий внутрішній продукт

$\mathrm{CC}-$ Свропейський Союз

IT - Інформаційні технології

МВФ - Міжнародний валютний фонд

МОП - Міжнародна організація праці

НДДКР - Науково-дослідні та дослідно-конструкторські роботи НТР - Науково-технічні розробки

ПРООН - Програма розвитку Організації Об'єднаних Націй США - Сполучені Штати Америки 


\section{ВСТУП}

Підвищення рівня та якості життя населення залежать від соціально-економічного розвитку держави. На сучасному етапі соціально-економічний розвиток країн світу зазнає все більшого впливу від процесів цифровізації, які змінюють підходи вирішення проблем на різних рівнях і в різних сферах життя. Вони в основному спрямовані на пошук нових можливостей для підвищення добробуту та вирішення нагальних соціальних проблем: від охорони здоров'я, освіти та навколишнього середовища. Цифрові технології, що з'явилися протягом останнього десятиліття, допомагають знайти джерела підвищення ефективності та можливості стрімкого конкурентного розвитку ринкових бізнесструктур. Розвиток цифрової економіки в цілому та цифрових технологій зокрема зумовив появу нового поняття - “цифровий актив" - та стрімкий розвиток пов'язаних із ним процесів.

В аспекті посилення та загострення проблем соціальноекономічного розвитку національної економіки постає питання пошуку результативної моделі державного управління економіки в Україні, однією 3 ключових функцій якої $є$ прогнозування. Така проблематика є актуальною також з огляду на посилення проблем монополізації національних ринків, згортання малого та середнього бізнесу. Пріоритетним напрямом розвитку системи антимонопольного регулювання є зміна загальної концепції такого регулювання та запровадження європейської моделі антимонопольної політики. Проте можна впевнено стверджувати про необхідність уточнення теоретичних засад системи антимонопольного регулювання та побудови іiі структури 3 урахуванням функції прогнозування в умовах цифрової економіки.

Метою роботи $\epsilon$ розробка теоретико-методологічного підгрунтя, методичних підходів і практичних рекомендацій щодо прогнозування впливу цифрового активу на соціально-економічний розвиток підприємства. 


\section{РОЗДІЛ 1. ТЕОРЕТИЧНІ ОСНОВИ СОЦІАЛЬНО-ЕКОНОМІЧНОГО РОЗВИТКУ В СУЧАСНИХ УМОВАХ}

Розуміння концепції соціально-економічного розвитку в економіці змінилося 3 початку виникнення самої дисципліни: від економічного зростання через економічний розвиток до соціальноекономічного розвитку.

Оскільки світова економіка змінюється так швидко, ключові рушійні сили, що лежать в основі глобальних соціальноекономічних змін, включають зміни в моделях виробництва та споживання, включають нові технологічні інновації та способи ведення бізнесу, а також соціальні та політичні зміни.

В контексті розгляду цього явища важливо дослідити особливості соціокультурного контексту, які формують його розуміння, а також вплив сучасних інформаційних технологій, які істотно змінюють моделі та способи ведення бізнесу.

Технологія є ключовим фактором цих змін; нові технології значно поліпшили сфери виробництва, фінансів, комунікацій та інші, завдяки чому світ швидко інтегрується в єдиний ринок. Торгівля і прямі іноземні інвестиції, поряд 3 більш широким географічним поширенням зростання доходів i можливостей, сприяють подальшій інтеграції зростаючого числа країн в більш широкий міжнародний обмін.

Згідно останніх даних, представлених Світовою організацією торгівлі, торгівля і глобалізація в цілому принесли величезні вигоди багатьом країнам i громадянам. Торгівля дозволила країнам отримати вигоду зі спеціалізації і економіки, щоб виробляти в більш ефективних масштабах. Це підвищило продуктивність і доходи, стимулювало економічне зростання, сприяло поширенню знань i нових технологій, а також розширило діапазон вибору, доступного для споживачів.

Глобальна торгівля, потоки товарів i послуг мають вирішальне значення для досягнення стійкого зростання в країнах, що розвиваються. Поряд 3 торгівлею зростаючі потоки капіталу через національні кордони вносять значний вклад в економічне 
зростання і скорочення бідності. Міжнародна мобільність і поділ праці теж призводять до істотних змін у розподілі по країнам.

Багато урядів країн, що розвиваються, останнім часом відкрили свою економіку для міжнародної торгівлі за допомогою багатосторонньої торговельної системи, розширення регіональної співпраці або в рамках програм внутрішніх реформ соціальноекономічного розвитку.

Незважаючи на нещодавню глобальну економічну кризу, світова торгівля різко зросла за останне десятиліття, збільшившись майже в три рази. Розвинені країни, як і раніше, є основними гравцями в міжнародній торгівлі, в той же час спостерігається зростання частки країн, що розвиваються. Інтеграція країн, що розвиваються, в світову економіку, незважаючи на гарні результати в цілому, була досить різноманітною. Східна Азія продовжує домінувати в торгових потоках країн, що розвиваються, в той час як інші регіони сильно відстають. Китай стає все більш важливим торговим партнером для багатьох інших країн, що розвиваються, не тільки у східно-азіатському регіоні, але і в країнах Африки (на південь від Сахари) і в Латинській Америці.

За офіційними статистичними даними Міністерства розвитку економіки, торгівлі та сільського господарства України ми можемо дослідити динаміку стану економічного розвитку в Україні за останній рік [1].

За показниками приросту/зниження:

- промислового виробництва: 0,0\% (січень-вересень, 2019);

- сільськогосподарського виробництва: $+5,9 \%$ (січеньвересень, 2019);

- капітальні інвестиції: +12,3\% (січень-червень, 2019);

- прямі іноземні інвестиції: $+2,6 \%$ (станом на 01.07.2019);

- зовнішня торгівля товарами (сальдо): $-5842,7$ млн. дол. США (січень-серпень, 2019);

- зовнішня торгівля товарами (експорт): $+6,9 \%$ (січеньсерпень, 2019);

- ринок праці (за методологією МОП): 8,5\% (січень-червень, 2019);

- ринок праці (оплата праці): +9,5\% (січень-вересень, 2019); 
- споживчі ціни (до грудня попереднього року): $+3,4 \%$ (вересень 2019 до грудня 2018);

- споживчі ціни (до попереднього місяця): $+0,7 \%$ (вересень 2019 до серпня 2019).

Отже, наведений Міністерством аналіз економічного розвитку в Україні $\epsilon$ важливим, але обмеженим засобом дослідження соціально-економічного розвитку держави, оскільки не враховує соціокультурний контекст, пріоритети, визначені міжнародними установами тощо.

Наше дослідження відкриє нові можливості для системного аналізу цього складного процесу в країнах ЄC за останнє десятиріччя та на цій основі дозволить спрогнозувати тенденції розвитку економіки України з урахуванням поглядів міжнародних установ, впливу соціуму та ринкових відносин, а також сучасних цифрових технологій на цей процес у цілому.

Розглянемо явище соціально-економічного розвитку більш грунтовно.

Сьогодні виявленням кращого визначення соціальноекономічного розвитку i чинником, який впливає на спосіб розуміння цього явища, є головним чином документи міжнародних установ (наприклад, агентств з розвитку, Програми розвитку ООН (ПРООН), Продовольчої та Сільськогосподарської Організації ООН (ФАО), Міжнародного валютного фонду (МВФ), Світового банку) і декларації країн, які співпрацюють для досягнення цілей цього розвитку. Наприклад, цілі в галузі розвитку, сформульовані в Декларації тисячоліття, запропоновані ПРООН у 2000 р., включають скорочення масштабів убогості, охорону здоров'я, стале використання ресурсів, освіту, продовольчу безпеку і сприятливе управління. Міркування про розвиток більше не сприймаються в контексті боротьби з бідністю у регіонах, які відстають. Таке широке розуміння соціально-економічного розвитку відіграє важливу роль. Цей поворот пов'язаний зі зростаючим значенням гуманізму, а також з філософськими та соціологічними ідеями щодо рівності можливостей. Очевидно, що популярність турботи про навколишне середовище і усвідомлення ролі соціального капіталу також є важливими факторами. 
Економічне зростання, яке $\epsilon$ “незмінним i природним економічним правом”, проявляється у збільшенні загального обсягу виробництва, що веде до покращення умов життя населення. Теорія економіки дає три причини економічного зростання: накопичення капіталу, приріст населення та технологічний прогрес. Сьогоднішня дискусія щодо визначальних факторів зростання вказує на додаткові питання, такі як: інвестиції у виробничий капітал, інвестиції в людський капітал, НДДКР, відкритість до торгівлі та доступ до розвинених фінансових ринків. Це доповнюється відповідною економічною політикою, яка дозволяє підтримувати інфляцію на бажаному, стабільному рівні та правовими та інституційними умовами, що створюють сприятливе для бізнесу середовище, яке заохочує стартування бізнесу.

Нерівномірний розподіл факторів зростання негативно позначається на місцевій, національній та регіональній економіці. Ця ситуація відбивається на нерівномірному економічному розвитку, що означає різнобічний соціальний розвиток. Диспропорції в соціально-економічному розвитку, в свою чергу, негативно впливають на ефективне використання наявних економічних ресурсів і визнаються головним бар'єром для економічного розвитку.

Питання, як зменшити відмінності в соціально-економічному розвитку, є предметом досліджень та практичного виміру концепції Європейського Союзу. Трансформація Європейського Співтовариства в Свропейський Союз, економічний та валютний союз, змусила вжити заходів для зменшення нерівності в економічному розвитку між членами. Відповідно до Договору про Європейський Союз: “у всій своїй діяльності Союз має на меті усунути нерівності (...)” [2]. Це має здійснюватися політикою згуртованості, сфера діяльності котрої (просторова та часова) розвивалася протягом багатьох років. Раніше політика згуртованості була зосереджена на планах та їх фінансуванні в рамках національної політики; з часом інвестиційний горизонт та просторовий масштаб - від внутрішніх інвестицій до транскордонних або регіональних інвестицій (макрорегіони ЄС) були розширені [3]. Досягнення цілі Договору про СС вимагало більшої фінансової прихильності до регіонів із слабшими 
економічними умовами. Вони включали переважно країни Центральної та Східної Свропи, які приєдналися до СС у 2004, 2007 та 2013 роках. Хоча спочатку скорочення нерівності обмежувалось насамперед зменшенням розриву між ВВП на душу населення та рівнями безробіття, зміни в пріоритетах розвитку СС спричинили зміну у сприйнятті - тепер важливішим було те, які нерівності слід зменшити. Економічні показники (ВВП, рівень безробіття) були виправдані при оцінці виконання Лісабонської стратегії, яка передбачала, що Європа стане найбільш економічно конкурентоспроможним регіоном до 2010 року. Відсутність успіху в реалізації цієї стратегії призвела до зміни пріоритетів Політики ЄС. Нові пріоритети описані в стратегії “Свропа 2020”, яка передбачає, що до кінця другого десятиліття 21 століття Свропа буде більш узгодженою, ніж будь-коли, і іï розвиток буде: “... розумним шляхом більш ефективних інвестицій в галузі освіти, досліджень та інновацій; стійкий, завдяки рішучому просуванню до економіки з низьким вмістом вуглецю; та інклюзивний, з сильним акцентом на створення робочих місць та зменшення бідності" [4]. 3 огляду на вищезазначені пріоритети розвитку, виникла потреба розширити набір показників на п’ять напрямів: (I) зайнятість, (II) науково-дослідні роботи, (III) зміна клімату та енергетика, (IV) освіта; (V) боротьба з бідністю та соціальним відчуженням, розміри яких становлять основу для оцінки прогресу у досягненні цілей. У документі GDP and beyond. Measuring progress in a changing world [5], крім доповнення екологічних та соціальних показників, Європейська Комісія також запропонувала [5, с. 5-11]:

1) інформацію в режимі реального часу для прийняття рішень;

2) більш точне звітування про розподіл та нерівності;

3) розробку табло європейського сталого розвитку;

4) поширення національних рахунків на екологічні та соціальні питання.

Модифікований підхід до питання, як виміряти нерівності між регіонами, також дещо змінив обсяг питань, що охоплюються політикою згуртованості. У фінансовій перспективі на 2014-2020 роки велика увага приділялася, крім безробіття, промисловості та сільського господарства, розбіжностям у частині: “... інновацій, 
рівня освіти, навколишнього середовища та бідності” [3, с. 200]. Що необхідно для прискорення зростання: ефективне використання наявних ресурсів і зв'язок економік транспортними системами та інформаційними технологіями. Відповіддю на ці питання $\epsilon$ фінансовий інструмент СC (Connecting Europe Facility - CEF), головна мета якого - підтримка економічного зростання, підвищення рівня зайнятості та конкурентоспроможності економіки СС шляхом фінансування інфраструктурних інвестицій, здійснених у рамках співпраці - щодо СС рівня. Проекти, що фінансуються CEF: “... заповнення відсутніх ланок в європейській енергетиці, транспорті та цифровій основі” [6].

Економіки Центральної та Східної Європи, які приєдналися до Європейського Союзу як останні (останні три розширення ЄС: 2004, 2007, 2013), відрізнялися від економік попередніх країнчленів СС. Це було наслідком політичного та економічного поділу Європи на дві області після Другої світової війни. В економічному плані це сфери: ринкова економіка та централізована планова економіка. Політичні та економічні перетворення, розпочаті наприкінці 1980-х, дозволили деяким країнам приєднатися до Європейського Союзу. Членами СС (з цього регіону Європи) у 2004 році були: Естонія, Латвія, Литва, Польща, Чехія, Словаччина, Словенія та Угорщина, у 2007 році: Болгарія та Румунія, а в 2013 році - Хорватія. Відмінності між так званими старими та новими членами $\mathrm{CC}$ виявились у всіх аспектах функціонування держави: врядування, економічне, соціальне, правове, фінансове тощо. Слабкими сторонами постсоціалістичної економіки були: неефективні та збиткові економічні структури, міцні зв'язки 3 радянською економікою (найбільший, часом єдиний експортер ресурсів та імпортер готової продукції), затримка порівняно із Західною Європою у розвитку ключових галузей: транспорту, енергетики та зв'язку. У 2014 році спільний звіт був підготовлений Енергетичними партнерами Центральної та Східної Свропи (СЕЕР) спільно з Інститутом CEED за підтримки Групи LOTOS S. A. та Oil Exploitation Enterprise S.A. PERN "Friendship": Completing Europe From the North-South Corridor to Energy, Transportation, and Telecommunications Union [7]. У звіті представлена можливість “завершити інтеграцію” Свропейського Союзу шляхом створення 
мережі енергетичних, транспортних та комунікаційних зав'язків у країнах Центральної та Східної Свропи. У звіті, крім так званих нових членів Свропейського Союзу, Австрія також була включена через стратегічне розташування в запропонованому інфраструктурному коридорі Північ-Південь. Ініціативу тісної співпраці між колишніми соціалістичними країнами вперше просунув президент Хорватії. Початком спільних зусиль для зміцнення країн Центральної та Східної Свропи стала зустріч у Нью-Йорку з нагоди сесії ООН восени 2015 року. Назва "Ініціативи трьох морів" (“The Three Seas Initiative”) була запропонована як посилання на зону, яка підлягає охопленню - європейські держави між Балтійським, Адріатичним та Чорним морями. Хоча країни, запрошені до Ініціативи, становлять майже $43 \%$ усіх членів $\mathrm{CC}$, вони становлять менше $30 \%$ поверхні $€ \mathrm{C}$, а їх населення становить трохи більше $20 \%$ населення СС.

Це означає, що членами Ініціативи є невеликі країни, як за площею, так і за кількістю населення. Як результат, відсутність економії на масштабах означає, що деякі інвестиції в транспорт, енергетику та транспортування не є прибутковими. Однак без цих інвестицій прогрес буде не таким швидким, як у країнах Західної Свропи (крім Австрії).

Метою Ініціативи $є$ вирівнювання рівнів розвитку економік, для досягнення яких потрібні дії для підвищення зв'язності, взаємодоповнюваності та, зрештою, процвітання. Енергетика, транспорт та цифровий зв'язок були визначені як ключові сфери співпраці.

Модифікований індекс соціального та економічного розвитку (SEDI) використовується для оцінки рівня розвитку. Індекс дозволяє проводити багатовимірний аналіз соціально-економічного розвитку та становища досліджуваної економіки щодо вибраних економік.

Показники включали заходи, пов'язані з різними соціальноекономічними аспектами. Їх вибір був тісно пов'язаний 3 пріоритетами, визначеними в стратегії “Свропа 2020”. У ході дослідження вивчено, наскільки великі відмінності між країнами, які зазнали політичних та економічних перетворень, і так званими старими членами Союзу. Оскільки дослідження стосувалося країн, 
що беруть участь в “Ініціативі трьох морів", Австрія була також проаналізована, крім постсоціалістичних країн. Показники SEDI були розраховані для всіх дванадцяти країн Ініціативи та для всього Європейського Союзу. Три обрані роки, за які розраховувались SEDI - 2004, 2009 та 2013 pp.

2004 рік, коли відбулося найбільше розширення Європейського Союзу, і його структури почали функціонувати у восьми країнах Центральної та Східної Європи. Таким чином, показники SEDI показали становище цих країн на відміну від Австрії та СС в цілому. Хоча наступне розширення відбулося у 2007 році, було оцінено ще один SEDI лише у 2009 році. Це був п'ятий повний рік, коли вісім країн діяли в СС та третій рік членства Болгарії та Румунії. Крім того, у 2009 році економіка зазнала більшості наслідків фінансової кризи, і це відобразилось на річних показниках. 2013 рік був обраний роком останнього розширення $\mathrm{CC}$ до Хорватії.

На основі отриманих результатів зроблений висновок, що постсоціалістичні держави не лише вступили до ЄС зі значно слабшими економіками, але й не в змозі ефективно зменшити свої соціально-економічні прогалини, незважаючи на функціонування в межах ЄС. У 2004 році найбільше значення було досягнуто для економіки всього Європейського Союзу, за ним - Австрія. У 2004 p. тільки Словенія та Естонія досягли рівня вище середнього показника SEDI. Усі інші країни мають нижчі значення середнього показника SEDI. Найвизначнішими економіками у 2004 році були Хорватія, Болгарія та Румунія, які ще не були членами ЄС у досліджуваному році. У 2009 році, за винятком Словенії, “нові” країни Свропейського Союзу отримали нижчі значення середього рівня показника SEDI. Це було наслідком фінансової кризи, яку особливо відчували найслабкіші економіки. У випадку Австрії, Словенії або всього Європейського Союзу показник зростав, це означає, що незважаючи на складні економічні умови, відбулося соціально-економічне зростання. Економічно слабкі країни сильно постраждали від економічного спаду, який проявився особливо у високих рівнях безробіття, уповільненні інвестицій та менших інвестиціях в НДДКР. Найбільше зниження зафіксували Болгарія на $32 \%$, Польща на 25\% та Литва, Латвія та Угорщина на 22\%. Для 
того, щоб побачити, чи зростали нерівності між країнами у 20042009 роках, використовувався індекс Джині. Виявилося, що, хоча різниця в SEDI у 2004 році породжувала індекс Джині на рівні IG $_{2004}$ 0,100069, індекс Джині 2009 року збільшився до $\mathrm{IG}_{2009}=$ 0,196556 [8].

Суттєві відмінності в рівні соціально-економічного розвитку, що виникли в 2009 році, протягом наступних кількох років не компенсувалися. Хоча Європейський Союз в цілому трохи втратив значення SEDI (9\% порівняно з 2009 роком), і всі оцінені економіки зросли, це не означає рівного розвитку. У 2013 році економіка Австрії та середній рівень економічного розвитку СС значно відрізняються від решти. А також серед економік, які зазнали трансформації, спостерігається все більша диспропорція. Якщо у 2004 р. Лише дві “нові” країни мали SEDI вище середнього рівня в СC, у 2013 році вже чотири країни перевищили це середнє значення (Словенія, Чехія, Естонія та Латвія), а ще дві (Словаччина та Польща) показники лише дещо нижчі. На іншому кінці рейтингу значення SEDI були такими ж, як у Хорватії, Румунії та Болгарії. Протягом усього досліджуваного періоду половина економік збільшувала свій потенціал для вирішального соціальноекономічного розвитку, враховуючи темпи зростання SEDI - це Австрія (68\%), СС (26\%), Латвія та Чехія (13\%), Словенія (9\%) та Словаччина $(5,2 \%)$. Відсутність прогресу у досягненні цілей "Свропа - 2020" зі зниженням значень SEDI було зафіксовано у Болгарії (-26\%), Хорватії (-12\%), Естонії (-6\%), Литві та Румунії ($5 \%)$, Угощині (-4\%) та Польщі (-1\%). Незважаючи на те, що різні напрямки змін були відмічені в обстежених економіках, діапазон яких був високим (від 68\% зростання SEDI до 26\% в SEDI), зміни SEDI в регіоні Ініціативи незначно зменшилися порівняно з 2009 роком, хоча все ще був вищим, ніж у 2004 році. Індекс Джині становив: $\mathrm{IG}_{2013}=0,16$.

Отже, країни, які приєдналися до Ініціативи, зберігають величезну різницю в соціально-економічному розвитку, що вимірюється SEDI. Австрія залишається вирішальним лідером у своєму розвитку. Серед країн, які зазнали системних перетворень, соціально-економічні умови в Словенії та Чехії найбільш швидко змінилися. Найгірша ситуація була в балканських країнах: Болгарії, 
Румунії та Хорватії. 3 одного боку, слабке становище трьох країн із найнижчими SEDI може бути пов'язане з найкоротшим періодом членства в Свропейському Союзі. 3 іншого боку, це може означати також неможливість подолання слабких сторін, які різною мірою вплинули на всі економіки під впливом Радянського Союзу. Це підтверджується показником Джині, який показує, що під час глобального спаду значно постраждали від кризи “нові” держави ЄС. Диверсифікація економічного розвитку значно поглибилась. Світове економічне відновлення допомогло деяким економікам (Словенія, Чехія, Естонія, Латвія, Словаччина та Польща), але щодо Болгарії чи Румунії зміни були майже непомітними. Відображенням цієї ситуації було незначне змінення значення індексу Джині з 0,19 (у 2009 році) до 0,16 (у 2013 році).

Таким чином, проведений аналіз свідчить, що в державах "Ініціативи трьох морів" немає належного потенціалу для забезпечення цих економік більш швидким та кращим зростанням, що відповідає цілям Свро-2020.

Розглянемо явище соціально-економічного розвитку в контексті ринкової економіки, зокрема 3 точки зору впливу суб'єктів та організаційних підрозділів державного сектора на процеси соціально-економічного розвитку.

В умовах ринкової економіки соціально-економічний розвиток розглядається як результат взаємодії організаційних структур та підрозділів державного сектора, роль яких полягає у підтримці та стимулюванні розвитку, особливо серед організацій приватного сектору, які відповідають за фактичний хід економічних процесів, пов'язаних 3 ринковим виробництвом товарів і послуг. Тому проведення досліджень взаємозв'язків між організаціями, організаційними підрозділами, що входять до складу державного сектору, та підприємствами, що працюють у реальній сфері ринкових умов, призводить до встановлення фактичного причиннонаслідкового зв'язку, а також ролі та важливості конкретних груп суб'єктів та їх вплив на перебіг економічних процесів у ринкових умовах. Тут особливу роль відіграють принципи та методи надання соціальних послуг. У контексті цього дослідження соціальні послуги включають усі адміністративні заходи, що стосуються соціальних потреб громадян, медичних служб, освіти, 
персональних соціальних послуг, послуг 3 догляду, житлових послуг, служб зайнятості та спеціалізованих служб, а також грошових переказів для різних груп населення суспільства.

У сучасних нестабільних умовах економічних ринків, а також дедалі більш нестабільних ринкових механізмів у Європі та світі необхідно перевірити як можливості, так і загрози щодо підтримки соціально-економічних процесів в умовах ринкової економіки. Важливо звернути увагу на значно різноманітний спектр завдань та обов'язків організаційних структур та підрозділів, що входять до складу державного сектору, та підприємств, що працюють у реальній сфері ринкових умов. Слід підкреслити, що інвестиційні витрати є найважливішим фактором, що безпосередньо впливає на рівень та якість надання державних послуг, включаючи рівень та якість соціальних послуг.

Однак ширший контекст процесів розвитку, включаючи роль державного сектора та соціальних служб, не можна не помітити, особливо що стосується проблем глобального розвитку, загалом визначених у концепції економіки розвитку. Відповідно до концепції економіки розвитку слід шукати оптимальний розподіл ресурсів та підтримувати економічне зростання для бідних країн, які не завжди беруть участь у процесах глобалізації та розвитку.

Тому наступне завдання дослідження - виявити та проаналізувати поточні можливості та обмеження, що виникають у процесі фінансового розвитку на регіональному та місцевому рівнях, в умовах ринкової економіки країн $\mathrm{CC}$.

Основна увага дослідження обмежується визначенням ролі організаційних структур та підрозділів державного сектору у процесі підтримки економічного розвитку та надання соціальних послуг.

В умовах ринкової економіки економічні та соціальні явища можуть вивчатися як в макроекономічному вимірі, так і з певної територіальної точки зору. Аналогічна закономірність стосується форми вищезазначених відносин між суб'єктами державного та приватного секторів. Значний обсяг впливу державного сектору на економіку реалізується на рівні держави, діями урядової адміністрації, включаючи обидві функції створення нормативноправових актів на рівні виконавчої влади та ряд заходів на рівні 
публічних втручань 3 сильною фінансовою компонентою, а також контрольними функціями. При цьому особливу увагу слід приділяти діяльності, що має прямий фінансовий вимір, котра здійснюється за рахунок інвестицій, що фінансуються за рахунок державного бюджету або системи проектно-орієнтованих субсидій, адресованих різним галузям економіки та використовується для підтримки реалізації певних соціальних та економічних цілей, i особливо для підтримки процесів, пов'язаних із наданням соціальних послуг.

Незважаючи на безсумнівно важливу роль державної підтримки, яку здійснюють на центральному рівні, нинішні тенденції соціально-економічних змін свідчать про необхідність ретельного аналізу проблем розвитку 3 місцевої точки зору. Сутність регіонального підходу до економічних та соціальних процесів полягає у виявленні потенціалу розвитку самого регіону, зовнішніх умов, що формують позицію регіону щодо ділового середовища, а також визначення компетенцій та взаємозв'язків між суб'єктами, які мають доступ до різних економічних ресурсів регіону та формування можливостей та форм їх застосування. Зважаючи на це, варто зазначити особливу роль суб'єктів державного сектору на регіональному та місцевому рівнях.

У цій структурі місцеве самоврядування регіону виконує важливі функції щодо адміністративної території, котра підпорядковується вищевказаному уряду. Це, зокрема, функції, що координують низку заходів, орієнтованих на розвиток, що здійснюються органами місцевого самоврядування районів. 3 точки зору формування майбутніх соціальних та економічних явищ на місцевому та регіональному рівні, певну увагу слід приділяти інструментам стратегічного управління, довгостроковим інвестиційним програмам, довгостроковому фінансовому управлінню матеріальним майном, що належить органам місцевого самоврядування, як основна сфера процесу прийняття рішень, наслідки якої мають прямий зв'язок - процес підвищення якості життя мешканців цієї адміністративної одиниці.

Обсяг компетенцій, а також сфера відповідальності місцевого самоврядування можуть відображатися у багатьох сферах адміністративної та службової діяльності, а також інвестиційній 
діяльності, що значною мірою визначають ефективність коротко- та довгострокового формування умов розвитку. Тому важливим завданням місцевого самоврядування $\epsilon$ проведення аналізу та прийняття рішень щодо реалізації інвестицій, запропонованих соціальними групами (радами, соціальними організаціями тощо), а також врахування ініціатив та пропозицій, поданих потенційними зовнішніми інвесторами.

Що стосується інвестицій, здійснених безпосередньо органами місцевого самоврядування, необхідно належним чином оцінити раціональність таких проектів, що може бути продемонстровано підготовкою кожного інвестиційного проекту 3 точки зору його масштабу, посилаючись на фактори, такі як кількість майбутніх користувачів та функції, характерні для елементів технічної та соціальної інфраструктури. Одним 3 важливіших факторів може бути масивність інфраструктурних елементів, що часто визначає недостатню обгрунтованість для здійснення інвестиційних проектів невеликого матеріального, а отже фінансового масштабу, як наслідок - нав'язування необхідності реалізації масштабних складних проектів з високими фінансовими витрати.

Роль органів місцевого самоврядування в контексті формування явищ розвитку проявляється виконанням намічених намірів, всебічно описуючи всі сфери функціонування та особливий характер даного підрозділу, i, одночасно, зберігаючи сферу компетенцій, що є адекватним для державного сектору. Сучасні умови ринкової економіки більшою мірою змушують досягти певного рівня економічної ефективності дій, що здійснюються місцевими громадами. Крім того, поряд із цивілізаційним прогресом зростають соціальні очікування, включаючи як суворіші екологічні вимоги, так i необхідність впровадження нових технологій, що породжує необхідність забезпечення більшого обсягу коштів, призначених на будівництво, обслуговування та модернізацію компонентів інфраструктури. Прагнення досягти зростання ступеня соціальної задоволеності в умовах ринкової економіки щодо державного сектору відповідає розробці нових концепцій управління, включаючи менеджмент, заснований на 
аналогії між управліннями, що надають державні послуги, та менеджмент організації, зосереджений на прибутку.

У країнах $\mathrm{CC}$, як і в будь-яких інших високорозвинених країнах, зміна способів наближення до проблеми управління суб'єктами та організаційними підрозділами в державному секторі, включаючи підрозділи місцевого самоврядування, рухається до підвищення ефективності та ефективного функціонування, а також забезпечення соціальними послугами. Важливі зміни у сфері формування процесів розвитку пов'язані із збільшенням самостійності підрозділів місцевого самоврядування та популяризацією, принаймні в орієнтовному відношенні, ставлення "менеджера", який спонукає до більшої активності та відповідальності за виконані завдання, включаючи необхідність нових, більш ефективних рішень стратегічного планування та прогнозування наслідків дій на майбутні періоди.

Ця проблема має ширший соціальний та економічний характер, оскільки виходить за межі держав та регіонів. Це проявляється у ряді проблем у різноманітних формах організації та функціонування держави та суспільства, у багатьох демографічних проблемах та багатьох проблемах надання державних послуг. $\mathcal{C}$ багато прикладів, коли ці проблеми призвели до низки небезпечних напружень у світі. Одним із можливих рішень $є$ посилання на концепцію економіки розвитку.

Що стосується підрозділів місцевого самоврядування, важливою проблемою є функція системи об'єднання ресурсів та фінансування різноманітних державних завдань. У цьому аспекті це проблема як рішень щодо загального розміру державних коштів, так і рішень щодо їх детального використання. Це також пов'язано 3 питаннями фінансової незалежності місцевого самоврядування, а отже і рівня незалежності окремих підрозділів стосовно органів державної влади центрального рівня. Значною мірою незалежність та фінансова стабільність місцевого самоврядування, а отже, здатність забезпечити належний процес надання державних послуг та можливості довгострокового підходу у формуванні розвитку певної адміністративної одиниці визначаються структурою бюджетних доходних ресурсів. У той же час, варто підкреслити, що основу фінансової економії органів місцевого самоврядування 
становить бюджет, який є децентралізованим планом доходів i витрат.

Вищезазначені міркування вказують на критичну проблему системного формування джерел доходів бюджету підрозділів місцевого самоврядування, зокрема включаючи пошук оптимального співвідношення доходів, що називаються власними та зовнішніми доходами, включаючи в цьому випадку трансферти 3 державного бюджету та субсидії з державних коштів . Високий рівень власного доходу, враховуючи водночас їх стабільність, можна вважати одним із життєво важливих факторів фінансової незалежності місцевого самоврядування. Це, в той же час, не зменшує значення зовнішнього доходу, оскільки, незважаючи на його, безперечно, обмежуючий характер фінансової незалежності, цей дохід $є$ важливим елементом регіональної політики, виконуючи функцію підтримки у вибраних сферах, і в той же час, контролюючи окремі сфери фінансової економіки місцевого самоврядування через державні установи державного управління. Аналізуючи проблему незалежності, ми повинні, таким чином, визначити сферу свободи, якою фактично володіють підрозділи місцевого самоврядування, не тільки щодо об'єднання бюджетних коштів, але і щодо їх витрачання. Чим більше масштаб такої незалежності органів місцевого самоврядування, тим автономнішими стають суб'єкти, які беруть участь у процесі розвитку.

Якщо припустити спрощений підхід до питання фінансової незалежності, виходячи 3 характеристик вищезгаданої категорії доходів, можна констатувати, що незалежність щодо доходу може бути забезпечена лише тоді, коли домінуючу роль у фінансуванні органів місцевого самоврядування відіграє власне дохід. Що стосується самостійності витрат, то вона збільшиться разом зі збільшенням частки власного доходу та загальних субвенцій у структурі доходів підрозділів місцевого самоврядування. Згідно 3 цим підходом, було б набагато простіше забезпечити самостійність щодо витрат, оскільки як власний дохід, так і загальна субвенція розподіляються на основі рішень, прийнятих законодавчими та виконавчими органами місцевих органів влади.

Аналіз фактичного ступеня фінансової незалежності місцевого самоврядування представляється досить складним 
завданням, враховуючи неоднозначну оцінку критеріїв цих проблем. Тим не менш, можна використовувати аналіз визначених індексів, включаючи індекс оцінки частки власного доходу підрозділів місцевого самоврядування у доході сектору державних фінансів загального обсягу або індекс частки власного доходу одиниць місцевого самоврядування у його доході в цілому. Зростання розмірів цих індексів означає поліпшення фінансової незалежності місцевого самоврядування.

Погіршення економічної ситуації та зменшення доходів у реальній сфері спричиняють обмеження поточної діяльності, зменшення витрат (часто за рахунок зниження рівня зайнятості) та обмеження обсягу інвестицій, а також зростання частки прийняття рішень про часткове припинення або повне припинення підприємницької діяльності. 3 точки зору державного сектору, вищезазначені явища призводять до значного ризику зменшення обсягу податків до державного бюджету, 3 якого частки перераховуються до бюджетів органів місцевого самоврядування. Характерна тенденція сучасних систем державного фінансування до бюджетного доходу “залежати від обсягу державних зборів" викликає посилення чутливості державного сектора, як до змін у реальній економіці, так i до перехресних відносин. Приклад економічної ситуації в деяких розвинутих країнах порівняно 3 уповільненням економіки у багатьох країнах ЄС у період після 2008 року вказує на провідну роль суб'єктів державного сектору у формуванні явищ розвитку в умовах фінансової кризи та залучення існуючих джерел фінансування державних витрат. Відсутність активності державного сектора спричинить додаткове погіршення стану інституційної інфраструктури, ослаблення регуляторних функцій державного управління та зниження якості державних послуг, у тому числі соціальних послуг, що, як наслідок, погіршить умови управління для приватного сектору.

В ході аналізу було зроблено припущення щодо еквівалентності умов розвитку та інвестицій - інвестиційні витрати можна вважати еквівалентом розвитку. Це випливає із зауваження, що за допомогою інвестицій підтримується економічний потенціал, дозволяючи збільшити його масштаби як кількісні, так і якісні, а також звертаючись до державних послуг, в тому числі соціальних. 
Що стосується підрозділів місцевого самоврядування, то принцип розробки зафіксовано у планових документах стратегічного характеру, включаючи проекти, що стосуються кількісних та якісних змін у майбутніх періодах.

Фінансування завдань місцевого самоврядування досі суворо пов'язане 3 необхідністю наздоганяти розвиток в галузі інфраструктури як економічної, так і соціальної. Незважаючи на сприятливу ситуацію щодо спроможності генерувати кошти, виділені на інвестиційні проекти, слід приділяти більше уваги питанням участі зовнішнього капіталу у фінансуванні інвестиційних витрат, а також питанням зростання державного боргу, будучи чинниками, що вказують на наявність структурної невідповідності бази бюджетних доходів фактично визначеним у нових умовах потреб соціальних служб місцевих громад.

Важливим викликом у процесі прийняття рішень щодо розпочатих інвестиційних проектів органами місцевого самоврядування є раціональність витрачання державних коштів. Тому на етапі підготовки планів розвитку або інвестиційних програм слід вдосконалити методи аналізу щодо економічної ефективності конкретних інвестиційних проектів, а також впливу конкретного проекту на функціонування місцевої економіки. Послуги загального інтересу та соціальні послуги зазвичай характеризуються низькою ціновою гнучкістю та доходом попиту, що означає, що як зміни, що відбуваються з боку цін, так і дохід мало впливають на зміни попиту, а отже, на рівень попиту. Явище низької гнучкості попиту в цій галузі послуг має специфічний вплив на весь процес надання послуг. Крім того, деякі державні послуги, особливо соціальні, надаються безкоштовно, а це означає, що їх ефективність неможливо оцінити лише за допомогою інструментів фінансового аналізу. Аналогічно інвестиції, вкладені для збільшення основних фондів обслуговування наданих послуг, повинні, в більшій мірі, оцінюватися із застосуванням інструментів, що дозволяють вимірювати не тільки фінансові ефекти, але й вплив на стан природного середовища та соціальні ефекти, що формує майбутню привабливість районів територіальної одиниці як місця проживання та розвитку місцевого підприємництва. 
Беручи до уваги очікувані обмеження наявності зовнішнього інвестиційного капіталу, що не підлягає поверненню, у бюджетній економіці певної одиниці місцевого самоврядування $є$ важливий елемент, який полягає у підтримці балансу бюджету та безпечного рівня заборгованості. Зважаючи на недостатній рівень соціальнотехнічної інфраструктури, який все ще присутній у численних підрозділах місцевого самоврядування, і явище, пов'язане з цією недостатністю, а саме очікування щодо швидшого задоволення колективних соціальних потреб, багато підрозділів беруть на себе реалізацію капітало-поглинаючі інвестиції в матеріальні активи. Занадто високий рівень заборгованості та пов'язані 3 цим довгострокові заборгованості можуть значно заблокувати або зменшити спроможність певного підрозділу робити нові інвестиційні проекти. Ці проблеми виникають досить часто. У перехідний період можна відновити структури держави та суспільства та спрямувати соціально- економічні процеси на шлях розвитку. Численні труднощі у функціонуванні держави та наданні послуг у державному секторі все ще існують у бідних країнах. У більш широкому контексті у багатьох бідних країнах світу дилеми розвитку все ще чекають ефективних рішень.

Як було зазначено раніше, в умовах ринкової економіки соціально-економічний розвиток $є$ результатом підприємницьких завдань, що реалізуються в організаціях, котрі працюють на відкритому ринку. Таким чином, можна сформулювати висновок про те, що потреба у взаємодії суб'єктів державного сектору та приватного сектора випливає 3 того, що підрозділи місцевого самоврядування відповідають лише за невеликий спектр завдань, включаючи переважно державні.

На цьому етапі варто зазначити важливість динамічно зростаючих груп учасників процесів розвитку на місцевому рівні співпраці органів місцевого самоврядування 3 неурядовими організаціями щодо надання послуг та соціальних інвестицій. Організації, що розглядаються як частина сектору неприбуткових організацій і складають водночас об'єкти соціальної економіки, можуть розглядатися як важлива $\mathrm{i}$ все ще розвиваюча група учасників соціально- економічних процесів у країнах $\mathrm{CC}, \mathrm{i}$ котрі 
поступово вирішують значну частину соціальних завдань, які донедавна традиційно були надбанням держави.

Результати аналізу дають підставу стверджувати, що роль суб'єктів господарювання приватного сектору та суб'єктів державного сектору в процесах соціально-економічного розвитку $є$, безсумнівно, значною. Підрозділи органів місцевого самоврядування досі відповідають за формування явищ розвитку. Однак ця роль залишається обмеженою, тоді як центр ваги економічних ефектів був перенесений у реальну сферу та приватний сектор. Фінансова незалежність органів місцевого самоврядування була ослаблена через те, що органи місцевого самоврядування стали значно залежними як від зовнішніх, так і від повернених джерел фінансування. Зокрема, відшкодовувані джерела фінансування, призначені для досягнення інвестиційних цілей, мають довгостроковий вимір. Рішення, прийняті в таких випадках, можуть мати свої довгострокові наслідки, що перевищують поточний термін повноважень органів місцевого самоврядування, які беруть участь у процесі прийняття рішень. Незважаючи на існуючі гарантії безперервності прийняття рішень в державному управлінні, варто підкреслити важливість прямої відповідальності за будь-які потенційні наслідки вжитих дій, які можуть негативно вплинути на бюджетну ситуацію в майбутніх періодах. Як випливає 3 проведеного аналізу, відповідальність за прийняття рішень щодо розвитку та їх майбутні економічні та соціальні результати $\epsilon$ одними з найбільш значущих, i, водночас, найскладніших елементів участі суб'єктів державного сектору в економіці на місцевому рівні та в процесі формування та стимулювання його розвитку. Серед багатьох проблем, які все ще залишаються в силі, ми повинні перерахувати належну оцінку потреб соціальних служб, вдосконалення процесів підготовки інвестиційних проектів, включаючи врахування всіх відповідних інструментів планування та оцінки матеріального та фінансового обсягу проектів, а також відповідальність місцевого самоврядування, що проявляється у реалізації інвестиційних проектів, всебічно описуючи всі сфери функціонування даного підрозділу. Маючи на увазі весь минулий досвід, пов'язаний 3 функціонуванням органів місцевого самоврядування в країнах $Є С$, слід зазначити, що ці суб'єкти 
відповідальні за значну сферу надання державних послуг, включаючи соціальні послуги, які часто передбачають залучення капіталовкладень. У зв'язку з цим існують серйозні обмеження, що полягають у невідповідності обсягу заходів та обсягу завдань. Результатом цієї невідповідності $є$ пошук підрозділів місцевого самоврядування для джерела позабюджетного характеру, включаючи переважно джерела, що повертаються. Однак це може бути обмеженням у майбутніх можливостях фінансування розвитку. Організація соціальних служб все ще $\epsilon$ складним процесом. Ці послуги характеризуються високим попитом на інвестиційний капітал та високими операційними витратами. Важливою особливістю соціальних послуг $є$ безоплатність, що означає, що всі витрати, пов'язані з їх наданням, фінансуються державними структурами, а громадяни отримують послуги безкоштовно.

Швидкий розвиток нових платформ і технологій прискорив розвиток та темпи зростання сектора фінансових послуг, що привернуло більше уваги від регуляторів та політиків у різних юрисдикціях.

По всьому світу розвиток фінансових технологій робить революцію в галузі способу взаємодії людей 3 фінансовими послугами. Ці нововведення дозволяють швидше здійснювати платежі, більш безпечні транзакції, зменшити витрати на переказ коштів та дозволяють фінансовий доступ у сферах, де традиційні фінансові інструменти використати не можливо.

Оцифровка сьогодні стає частиною всього, і підприємства не $\epsilon$ винятком. Багато підприємств у світі (особливо в Північній Америці) мають цифрову освіту, і тому вони мають щорічно високу рентабельність, і ії переваги відображаються у ВВП країни та рівні зайнятості.

Україна лише починає цей шлях, адже в ній дуже низький рівень інвестицій в НДДКР і не має повної цифрової трансформації через інертність працівників та фінансову неприязнь керівництва, оскільки цифрову трансформацію вважають дуже дорогим кроком і не показують миттєвої користі в найближчому майбутньому.

Зазначимо, що європейські фонди відіграють велику роль у фінансуванні інвестицій у цифрову трансформацію та інновації. 


\section{РОЗДІЛ 2. КОМПЛЕКС БАЗОВИХ ПОНЯТЬ ФЕНОМЕНУ “ЦИФРОВИЙ АКТИВ|”}

Сучасний етап економічного розвитку суспільства характеризується формуванням нової сфери економіки - цифрової, обумовленої збільшенням ролі цифрових технологій та електронноінформаційних технічних засобів зв'язку в розвитку всіх головних галузей науки. Цифрові технології, що з'явилися протягом останнього десятиліття, допомагають знайти джерела підвищення ефективності та можливості стрімкого конкурентного розвитку ринкових бізнес-структур. Водночас вони потребують перебудови наявних бізнес-процесів на підставі нових цінностей, пріоритетів та орієнтирів, заснованих на клієнтоорієнтованості, інноваційності, унікальності, праві використання й передавання, синергії.

Розвиток цифрової економіки в цілому та цифрових технологій зокрема зумовив появу нового поняття - “цифровий актив" - та стрімкий розвиток пов'язаних із ним процесів.

На сьогодні поняття “цифровий актив" не має жодного комплексного визначення, яке б повністю розкривало суть терміна, що значно ускладнює розуміння багатьох процесів, пов'язаних із використанням цифрових активів, та достатньо часто впливає на спотворення та помилкове трактування інформації, закладеної в базис існування цифрових активів. Така термінологічна плутанина створює стійкі умови для подальшого укорінення суперечливості та неоднозначності не лише самого поняття “цифровий актив", але й перспектив його використання. Тому актуальним $є$ уточнення поняття цифрового активу.

Аналіз сучасних наукових публікацій та досліджень з питань цифрового активу свідчить, що сьогодні не існує чіткого визначення та розуміння цього поняття.

Так, одна група вчених [9-18] застосовує поняття "цифровий актив"; друга група [19-21] - поняття “криптовалюта”; третя група [22] - поняття “токен”; четверта група [23] - поняття "віртуальний актив”; п’ята група вчених [24-26] застосовує декілька понять одночасно як синоніми, тобто спостерігається тісне сплетіння понять. 
Під час розроблення термінологічного апарату нами враховувались рекомендації ДСТУ 3966-2000 [27].

Для обгрунтування сутності поняття “цифровий актив” в економіко-правовому аспекті було використано комплекс теоретичних методів дослідження: дедукції та індукції, аналізу та синтезу, порівняння, узагальнення, систематизації та інтерпретації результатів.

Уточнення поняття цифрового активу має базуватися на чіткому термінологічному визначення власно дефініції "цифра" (похідна “цифровий”) та “актив”.

Спочатку словом "цифровий” позначався термін, що описує інформацію, виражену за допомогою чисел. Дані, такі як зображення, звуки, слова, подаються у вигляді набору цифр (1 та 0) у двійковій системі, що отримує своє безпосереднє використання у комп'ютерній сфері [28]. У Тлумачному словнику використанням електронних систем інформацію у двійковий код, призначений для послідовного оброблення, збереження та передавання відповідної інформації. Ці визначення підтверджують, що термін "цифровий" тісно пов'язаний із процесами розповсюдження, інтеграції інформації та інформаційних технологій у різноманітні сфери діяльності та є невід'ємною частиною понять і процесів, що характеризують зміни, які відбуваються не лише в фінансовоекономічному секторі, але й в суспільстві загалом.

Також варто розглянути змістовне наповнення поняття “актив”. У Тлумачному словнику фінансів поняття “актив” трактується як предмет об'єктивної дійсності, чи то він матеріальний, чи нематеріальний, що має якусь цінність для його тримача [30]. В Енциклопедичному словнику [31] як актив визначаються складові майна, без урахування наявних боргів, тобто товари, готівка, цінні папери, векселі, машини, інструменти, землі й будови та ін. У свою чергу, в Сучасному економічному словнику одне 3 тлумачень поняття “активи” розкривається як сукупність грошей, майна, що належить суб'єкту господарювання (фірмі, підприємству, компанії), в які попередньо були вкладені кошти їхніх власників [32].

У процесі розгляду поняття “цифровий” виявлено, що він містить також і числові комбінації, i кодування різних видів i 
способів, і технологію переведення будь-чого в електронний формат (оцифровування). У більшості джерел поняття “актив" пов'язане 3 матеріальними або нематеріальними ресурсами та майновими правами. Це свого роду цінність, власником якої може бути як одна особа, так і підприємство чи суспільство загалом. Поєднавши ці два поняття, можна визначити цифровий актив як цінність, виражену в цифровому вигляді. Зважаючи на це, цифровий актив являє собою набір цифрових (двійкових) даних, які $\epsilon$ автономними, унікально ідентифікованими та мають певну цінність.

Використання терміна “цифровий актив” у сучасному розумінні першочергово викликано появою технології Блокчейн $\mathrm{i}$ криптовалют. У 2009 році було створено першу криптовалюту Bitcoin, яка стала новим феноменом у сфері економіки. Одночасно 3 Bitcoin було розроблено і технологію Блокчейн - розподілений реєстр, що становить вибудований за певними правилами послідовний ланцюжок із блоків транзакцій, де кожен наступний блок містить інформацію про попередній. Така логіка роботи Блокчейна дозволила забезпечити безпеку та прозорість транзакцій і процесів, що в ньому відбуваються, завдяки чому ця технологія знайшла своє застосування у багатьох сферах. Такі тенденції зумовили стрімкий розвиток цифрової економіки та викликали значну зацікавленість суспільства феноменом цифрових активів. Проте, зважаючи на неоднозначність трактування та відсутність базових критеріїв визначення, терміном “цифровий актив" часто називають те, що насправді ним не $\epsilon$.

Отже, під час уточнення поняття цифрового активу будемо дотримуватися певних сутнісно-смислових особливостей, поданих чотирма складовими: 1) економічною; 2) правовою; 3) інформаційною; 4) ціннісною.

Розглянемо їх детальніше, базуючись на таких методах дослідження: дедукції та індукції, аналізу та синтезу, порівняння, узагальнення, систематизації та інтерпретації результатів.

1. Економічна складова у контексті визначення поняття “цифровий актив”. Ця складова представлена у фінансовій сфері наявністю унікального ідентифікатора. 
Для того щоб обгрунтувати доцільність використання компоненти "У вигляді унікального ідентифікатора" у визначенні цифрового активу, розглянемо кожну дефініцію окремо. Згідно із Тлумачними словниками [29, 33] слово “унікальний” означає єдиний, рідкісний, неповторний, винятковий, рідкісний або такий, що існує в єдиному екземплярі. Слово “унікальний” походить від латинського unicum та означає “єдиний”. Зі всього різноманіття тлумачення “унікальний” потрібно відштовхуватися від значення “свого роду єдиний” для правильного розуміння цього поняття у визначенні цифрового активу.

У добу інформаційних технологій та розвитку комп'ютерної техніки термін “ідентифікатор” стійко асоціюється 3 інформаційним середовищем. Наприклад, як ідентифікатор у мережі може використовуватися Email, номер телефону або код.

Значення слова “ідентифікатор" у Великому тлумачному словнику сучасної української мови [34] звучить таким чином: ідентифікатор (від англ. identifier) - ім'я об'єкта програми (перемінної, масиву, структури, функції та ін.), що дозволяє звернутися до об'єкта; ознака, яка в цілому визначає сутність у заздалегідь визначеному просторі. Ідентифікатор завжди: а) єдиний - розглядається як неподільна (атомарна) лексема; б) тотожний указує лише на одну сутність; в) дійсний лише в одному адресному просторі.

Сутнісна характеристика ідентифікатора добре відображається у завданнях мов програмування у визначенні меж дії локальних змін [34]. У Короткому словнику 3 кібернетики ідентифікатор подано як умовне найменування (мітка, ім'я) сукупності інформації або ж групи даних, що дозволяє знайти та, відповідно, добути таку інформацію з пам’яті [35].

Щоб внести ясність у порядок подання документів до державного реєстру та регулювання обігу електронних документів юридичних та фізичних осіб, використовується термін “унікальний ідентифікатор" - логічна послідовність символів, за допомогою яких заявник передає на офіційному веб-сайті спеціального уповноваженого органу з питань державної реєстрації інформацію про стан розгляду надісланих ним електронних документів для реєстрації юридичної особи або фізичної особи-підприємця, а 
також отримує електронні документи, надіслані йому державним реєстратором [36]. Поняття “унікальний ідентифікатор” також використовується у сфері проведення електронних аукціонів та означає набір цифр і букв, який аукціонна платформа автоматично присвоює будь-якій розподіленій пропускній здатності, що була розподілена між користувачами відповідно до результатів електронного аукціону [37].

Унікальний ідентифікатор застосовується в інформаційних системах і призначений для ідентифікації певного об'єкта у мережі, а також дозволяє виключити будь-яку імовірність дублювання цього об'єкта та підтверджує його автентичність.

Грунтуючись на розглянутих інтерпретаціях понять “унікальний”, “ідентифікатор” і словосполучення “унікальний ідентифікатор", можемо зробити висновок, що компонента “У вигляді унікального ідентифікатора" вказує на форму подання цифрового активу та свідчить про наявність унікального імені. Буквено-числовий код, що присвоюється системою, у якій обертається цифровий актив, дозволяє відрізнити конкретний цифровий актив у розподіленому реєстрі даних та отримати необхідну інформацію про нього.

Властивість унікальності цифрового активу стала можливою iз появою технології розподіленого реєстру, структура якого саме $\mathrm{i}$ $\epsilon$ гарантом збереження інформації та можливості верифікації активу. Будь-які зміни, що вносяться до розподіленого реєстру (Блокчейну), автоматично приводять до генерування нового унікального ідентифікатора, що виключає можливість дублювання та неправомірного використання активу. Інформація про цифровий актив містить такі ознаки: місце його знаходження, реєстрації, законодавчі обмеження та інші характерні ознаки та властивості. Блокчейн забезпечує умови ідентифікації цифрового активу внаслідок присвоєння йому унікального хеш-коду, що дозволяє закріпити такий актив за певним суб'єктом.

2. Правова складова у контексті визначення поняття “цифровий актив”. Ця складова представлена в юридичній сфері похідною від права.

Для коректної інтерпретації компоненти "Похідний від права" необхідно визначити дефініції: “похідний” і “право". 
Насамперед варто звернутися до матеріалів словників. Так, відповідно до Тлумачного словника [29] під похідним слід розуміти вироблений або ж утворений від іншого об'єкта. У Тлумачному словнику [33] під похідним пропонують розуміти те, що виникає 3 будь-чого іншого, або ж утворене від чогось іншого.

У подальшому вважаємо за доцільне розглянути термін “право”. Варто зазначити, що поліпарадигмальний підхід до розуміння права зумовлений джерелами виникнення цього феномена, багатовіковою філософською полемікою навколо нього та, як наслідок, неоднозначністю тлумачення. Навіть більше, це слово $є$ багатозначним та використовується у повсякденній мові для позначення різних феноменів. Триаспектне розуміння терміна “право" було запропоноване у Тлумачному словнику російської мови [38], де право розглядається як: а) формалізована сукупність правил поведінки; б) наука, що вивчає відповідні формалізовані правила поведінки; в) міра можливої поведінки, свобода дій, надана державою.

Варто зазначити, що саме останній спосіб інтерпретації права у тлумаченні Ушакова Д. Н. [38] є найближчим до істинного розуміння у контексті визначення поняття “цифровий актив”. Саме ця мовна конструкція буде використана в авторському визначенні поняття цифрового активу - “право на". У цьому випадку “право” можна замінити на "гарантована можливість чого-небудь", водночас первинний зміст буде збережено.

Поділ права на його об'єктивне та суб'єктивне розуміння було використано також і у Великому юридичному словнику [39]:

a) об'єктивний зміст права - сукупність офіційних норм права, що встановлюються та забезпечуються державою (позитивне право); правила, що виникають із самої природи права, що стоїть над формальним законом (природне право);

б) суб'єктивний зміст права - міра можливої поведінки суб'єкта права (суб'єктивне право).

Отже, саме суб'єктивний зміст трактування права в цьому джерелі апелює до визначення поняття “цифровий актив”, що розглядається. Матузов Н. И. та Малько А. В. [40], з точки зору правової доктрини, визначають право як нормовану, впорядковану форму виявлення свободи, що спрямована у легітимне русло. 
Проаналізувавши значення різних понять слова “похідний”, можна дійти загального висновку: всі ці визначення поєднуються наявністю певного базового явища, предмета (виробляючого), що і зумовлює походження похідного. Іншими словами, “похідний” виникає у результаті трансформації виробляючого (базового явища) та до того ж здатний зберігати базові властивості або спиратися на них. Зі свого боку, властивості похідних зумовлені властивостями виробляючих.

Спираючись на вищенаведені визначення права, можна зробити висновок, що у визначенні поняття “цифровий актив” буде використано саме суб'єктивний підхід трактування права як вид $\mathrm{i}$ міра можливої поведінки особи, що регламентуються правовими нормами.

За результатами аналізу дефініцій компоненти “Похідний від права" можна стверджувати, що вони найповніше відображують суть покладеного у визначення поняття “цифровий актив" принципу. Цифровий актив не $є$ правом на цінність у його тлумаченні, проте він має властивості похідного від права на цінність.

3. Інформаційна складова у контексті визначення поняття “цифровий актив”. Ця складова в IT-сфері представлена інформаційним ресурсом, таким, що обертається у розподіленому реєстрі.

Компонента "Інформаційний ресурс" на сьогодні не має універсального всеосяжного визначення. Тлумачення цього терміна варіюються залежно від предметних галузей та підходів, у розрізі яких вони розглядаються.

У законодавчих актах поняття “інформаційний ресурс” визначається як:

а) сукупність документів у інформаційних системах: бібліотеках, архівах, банках даних та ін. [41];

б) організована сукупність документованої інформації, що містить бази даних, інші сукупності взаємопов'язаної інформації в інформаційних системах [42].

Поняття інформаційних ресурсів, сформоване в Енциклопедії сучасної України [43], визначає ці ресурси як інформацію, подану в конкретній формі та таку, що відповідно зберігається, 
накопичується, оброблюється та використовується зацікавленими особами. Інформаційні ресурси характеризуються своєрідною емерджентністю, оскільки інформаційний ресурс може сприяти формуванню нових знань. Інформаційні ресурси можуть бути інтерпретовані як людиною, так і комп'ютерною програмою. Долинко В. И. [44] зазначає, що інформаційний ресурс - це дані у будь-якій формі, що характеризуються можливістю їхнього багаторазового використання. У Фінансовому словнику [45] інформаційні ресурси визначаються як сукупність даних, що систематизовані для подальшого ефективного отримання необхідної інформації.

Поляков В. П. та Косарев В. П [46] акцентують увагу на тому, що у XX столітті значення інформації як ніколи починає зростати. Відповідно, це привело до появи на одному з конгресів ЮНЕСКО такої стійкої термінологічної конструкції, як “інформаційні ресурси". Інформаційні ресурси, на думку авторів, це продукт інтелектуальної діяльності. Особливою рисою інформаційних ресурсів, як позначають Поляков В. П. та Косарев В. П. [46], є той аспект, що вони не зникають через деякий період часу. Зі свого боку Шуремов Е. Л. [47] детермінує інформаційні ресурси як знання, що були зафіксовані на матеріальному носієві та можуть у подальшому бути застосовані зацікавленими особами. Водночас варто звернути увагу на позицію Прокопенко А. Н. [48], який говорить, що інформаційним ресурсом є не будь- яка інформація, а лише та, що була належним чином упорядкована та структурована. Що ж до Бачило И. Л. [49], то вона зазначає, що інформаційним ресурсом $є$ лише та інформація, що має практичну значущість, що надає йому соціальної значущості.

3 усіх зазначених визначень та уточнень цього поняття можна дійти висновку, що інформаційний ресурс - це структурована та організована певним чином інформація, зафіксована на матеріальному носії, яку можна зберігати, передавати, використовувати, поповнювати. Інформаційний ресурс має властивості практичної значущості та корисності, а також можливість багаторазового використання (“невичерпність”). На відміну від інших видів ресурсів (природні, економічні, часові) кількість і якість інформаційних ресурсів зростає у міру їхнього 
використання. Такий кумулятивний ефект поряд із розвитком сучасних технологій сприяє стрімкому примноженню інформаційного потенціалу суспільства загалом.

Отже, цифровий актив є інформаційним ресурсом у тому розумінні, що подана у цифровому вигляді інформація про цінність має такі основні властивості інформаційного ресурсу, як: a) інформація структурована за певними параметрами та категоріями; б) інформація фіксується на цифровому носії; в) інформацію можна зберігати, передавати, обмінювати, використовувати та ін.

Крім того, цифровий актив у нашому розумінні має додаткову властивість - інформація про цінність формується власником цієї цінності. Варто зазначити, що інформаційний ресурс у контексті визначення поняття “цифровий актив" втрачає таку характеристику, як можливість бути скопійованим необмежену кількість разів. Це зумовлено тим, що у розподіленому реєстрі кожен такий ресурс виражений у вигляді унікального ідентифікатора, завдяки чому забезпечуються стійкі умови гарантованої приналежності цифрового активу певному суб' єктові. Звідси випливає важливий висновок: цінність цифрового активу складається з його унікальності та достовірності, що забезпечується завдяки обертанню цифрового активу в розподіленому реєстрі. Грунтуючись на цих характеристиках, можна позначити також високу практичну значущість цифрового активу в економікоправовому аспекті.

Компонента "Такий, що обертається у розподіленому реєстрі” у контексті визначення поняття “цифровий актив”.

Розглянемо поняття “такий, що обертається”, спираючись на різноманітні джерела інформації. Так, у Фінансово-інвестиційному тлумачному словнику [50] поняття “такий, що обертається" вживається у контексті кредитно-грошових або ж фінансових цінностей, що підлягають подальшій передачі або ж продажу іншому суб'єкту. Враховуючи, що це поняття частіше за все використовується разом з іменниками, найповніше розкрити його значення можна у контексті. Так, у Фінансовому словнику [51] подається визначення поняття “інструменти, що обертаються”, під якими розуміють фінансові інструменти та цінні папери, що можуть 
бути об'єктом вільного цивільного (господарського) обороту (наприклад, векселі, облігації, чеки, варранти). Додатково варто врахувати також і синонімічний ряд до терміну, що розглядається, для ширшого розуміння його значення: такий, що обертається - що використовується, циркулює, курсує, переходить.

Також потрібно розглянути змістове наповнення такої категорії, як "розподілений реєстр". Поняття “розподілений реєстр" має досить багато визначень. Так, за даними Департаментів дослідження, статистики та грошової політики Федеральної Резервної Системи США, розподілений реєстр - це тип бази даних, що розподілена між вузлами мережі; визначена комбінація компонентів, що містить, зокрема, peer-to-peer networking, розподілене збереження інформації та криптографію, що може потенційно змінити те, як цифровий актив буде зберігатися, реєструватися і торгуватися [24].

За словами головного наукового радника Уряду Великобританії Уолпорта М., розподілений реєстр - це база даних активів, що може розподілятись мережею різноманітних сайтів, у різноманітних організаціях та географічних зонах. Також варто зауважити, що всі учасники мережі можуть мати свою ідентичну, власну копію відповідного реєстру. Зміни, що вносяться до реєстру, одразу відображаються в усіх копіях. Самі ж активи, що знаходяться у реєстрі, можуть бути юридичними, фінансовими, електронними або ж фізичними. Вірогідність та безпека активів, що зберігаються, забезпечується криптографічно [52]. Ця нова технологія розподіленого зберігання інформації іменується Блокчейн. Ця технологія дає можливість до того ж вести облік операцій як з матеріальними, так і нематеріальними активами. Технологія Блокчейн дозволяє оцифрувати інформацію; безпечно іï передавати. Переваги цієї технології полягають у наступному: незмінність; захищеність; прозорість [53, с. 3-4].

Савельев А. [54] визначає “децентралізований реєстр даних" як інформаційну систему, що містить базу даних розподіленого типу і котра містить інформацію щодо конкретних фактів і (або) дані про право на майно, що підтверджується за допомогою певних алгоритмів. 
Одна 3 ключових властивостей цифрового активу можливість обертатися у цифровому середовищі, а не копіюватися під час передавання з однієї електронної адреси (сховища, гаманця, комірки) до іншої. Об'єкт, що обертається (цифровий актив), обов'язково повинен мати не лише своє середовище обертання, але й чітко визначені правила та умови свого знаходження у такому середовищі. Для можливості встановлення та контролю виконання таких правил та умов потрібна надійна цифрова екосистема, iз можливістю масштабування та децентралізована, що дозволить усім учасникам бути впевненими у тому, що унікальність інформаційних ресурсів буде збережено. Саме тому компонента “Розподілений реєстр" посідає значиме місце у визначенні поняття цифрового активу.

Розподілена система зберігання даних таких реєстрів є однією 3 найбільш технологічно просунутих. Вона забезпечує максимально можливий рівень довіри до інформації завдяки обов'язковій процедурі ії перевірки на вірогідність усіма вузлами розподіленого середовища за допомогою визначеного способу забезпечення консенсусу. В такий спосіб вирішується також i проблема “подвійної витрати”. Інформацію, що міститься у такому реєстрі, неможливо видалити чи модифікувати, а надійність і механізм цього методу зберігання дозволяє створювати у реєстрі записи про право на цінності (активи). Це необхідна процедура у процесі створення цифрового активу, який, зі свого боку, потребує фіксації у реєстрі інформації про проведення оцінювання (аудиту) та інших даних власника цінності, що оцифровується, зокрема, і його права власності на цінність. Для розуміння суті цифрового активу важливо враховувати обов'язкові умови: можливість підтвердження приналежності цифрового активу певному суб'єктові, а також відсутність будь- яких способів створення копії того самого цифрового активу, зокрема, через дублювання його унікального ідентифікатора. Забезпечити такі умови може лише технологія розподіленого реєстру, що дозволяє гарантувати унікальність ідентифікаторів цифрових активів та зафіксувати конкретні ідентифікатори за конкретними об'єктами.

Отже, можна дійти висновку, що можливість обертання у розподіленому реєстрі для цифрового активу $\epsilon$ однією 3 
визначальних, тому розподілений реєстр як система зберігання інформації - єдине можливе середовище існування та обертання цифрових активів, які, по суті, є токінезованими інформаційними ресурсами, похідними від реальних активів у просторі розподіленого реєстру.

4. Ціннісна складова у контексті визначення поняття “цифровий актив”. Ця складова представлена у сфері матеріальних та нематеріальних благ компонентою “Цінність”.

Поняття "цінність" має низку визначень та тлумачень, що залежать від предметної галузі їхнього застосування. В Тлумачному словнику [55] поняття “цінність” розглядається як вартість конкретного об'єкта матеріальних або ж нематеріальних благ. Виокремлюються два підходи до детермінації вартості. Так, із точки зору класичної політичної економії (Classical school) вартість потрібно розглядати як об'єктивну реальність, що вимірюється через витрачену працю на виробництво тих чи інших благ. Зі свого боку, представники неокласичної школи (neoclassical school) прямо пов'язують вартість із рідкісністю запитуваного блага. Переважаючим на сьогодні є саме неокласичний підхід. Що ж до Енциклопедичного словника [56], то в ньому цінність визначається як позитивна або ж негативна значущість для людини об'єктів матеріального або ж духовного світу. Варіативністю визначень цінності вирізняється Тлумачний словник російської мови [38]. Так, на думку автора, як цінність варто розуміти значення, важливість, ціну конкретного явища чи предмета.

Iз наведених тлумачень поняття, що розглядається, можна зробити висновок, що цінність - це значення вартості, важливості, корисності чого- небудь, що може виражатися різноманітними одиницями виміру залежно від сфери практичного застосування такої цінності та екосистеми, в якій така цінність існує.

У визначенні поняття “цифровий актив” буде використано формулювання “похідний від права на цінність”, оскільки, по суті, цифровий актив є свого роду гарантованим правом претендувати на певне значення вартості (на цінність), закладену у цьому цифровому активі. Іншими словами, цифровий актив $\epsilon$ токінезованим інформаційним ресурсом, похідним від цінності. Отже, у визначенні поняття цифрового активу варто 
використовувати саме компоненту “Цінність”, оскільки вона найширше та всеосяжно виражає закладений у нього смисл.

На підставі встановлених сутнісно-смислових особливостей зробимо обгрунтування поняття “цифровий актив” у економікоправовому аспекті.

Цифровий актив - інформаційний ресурс, похідний від права на цінність і такий, що обертається у розподіленому реєстрі у вигляді унікального ідентифікатора.

Запропоноване поняття “цифровий актив” представлено складовими (економічною, правовою, інформаційною, ціннісною), що мають взаємозв'язок і взаємозалежність.

Розглянемо детальніше поняття, що використовуються у сучасних наукових публікаціях з питання цифрового активу.

На сьогодні ряд фахівців визначають криптовалюти як різновид цифрових активів. Так, провідний криптофахівець фінтехкомпанії Cinnober Wall [19] детермінує Ethereum як цифровий актив. Аналогічний підхід застосовує Цегоев В. [21] до визначення Bitcoin. Голова Ripple Garlinghouse [20] також схильний вважати Bitcoin цифровим активом, аргументуючи це тим, що Bitcoin надає користувачеві можливість вирішувати конкретні реальні проблеми, що обумовлює наявність у нього певної вартості.

Існує також підхід, відповідно до якого окремі категорії токенів прирівнюються до цифрових активів. Великая Е. [22] описує utility token як цифровий актив, який дає тримачеві відповідного токена право обміняти його у майбутньому на продукцію або послуги, що безпосередньо надаються емітентом відповідного токена.

Окрема група фахівців ототожнює цифрові активи 3 криптовалютою [24; 26].

Специфічний підхід простежується у роботі [25], де автор вивчав окремі аспекти оподаткування цифрових активів. Цифровими активами є об'єкти, що можуть обертатися у системах Блокчейн. Вчений не зводить цифрові активи виключно до криптовалют, тим самим, ніби спеціально залишаючи їх перелік “відкритим”. 
Social and economic foundation of the implementation of blockchain-based systems of digital assets in developing countries розглянуті у роботі [16].

Деякі фахівці розділяють терміни “криптовалюта" та “цифровий актив”, звертаючи увагу на принципову відмінність цих понять [9-18].

Buntinx J. P. [12] каже про те, що цифровий актив існує у бінарному вигляді та ним можна назвати будь-який тип цифрових даних: від кінофільму до папки на робочому столі. Головною відмінністю цифрових активів від криптовалют він вважає тип значень, що зберігаються, - у більшості криптовалют $є$ ліміт пропозиції, тоді як цифрові активи можуть (теоретично) створюватись нескінченно, якщо це потрібно.

Схожий підхід до визначення поняття цифрового активу був запропонований групою компаній Центру інноваційних технологій [9], які визначають як цифровий актив будь-які події, факти, їхні характеристики та описи, що були трансформовані у цифрову форму та, відповідно, такі, що мають деяку вартість. Так, до цифрових активів відносять такі елементи, як паролі, цифрові зображення, медичну інформацію, інструктивні записки та будь-які інші елементи, доступ до яких здійснюється головним чином за допомогою цифрових засобів, таких як книги, музика та фільми. Водночас серед цифрових активів (із юридичної точки зору) заведено також виокремлювати об'єкти інтелектуальної власності, а саме: авторські права, торгові марки, патенти та ін. [17].

Harbinja E. [15, c. 102] i Walker M. D. [18, с. 53] під цифровим активом розуміють будь-які об'єкти, що мають оцифровану форму.

Більш комплексними $є$ визначення цифрового активу, що отримали свою формалізацію у законотворчих актах. У Fiduciary Access to Digital Assets and Digital Accounts Act [13] отримало своє закріплення таке визначення цифрового активу: цифровий актив це дані, текст, електронні листи, документи, аудіо-, відеозображення, звуки, контент соціальних мереж, коди, записи про медичне обслуговування, записи медичного страхування, вихідні коди комп'ютерів, комп'ютерні програми, програмне забезпечення, програмне забезпечення ліцензій, баз даних та ін., включно 3 іменами користувачів i паролями, створеними, 
генерованими, надісланими, переданими, такими, що передаються, отриманим або такими, що зберігаються електронними засобам на цифровому пристрої.

New York's Fiduciary Access to Digital Assets Act [14] говорить, що цифровий актив означає деякий електронний запис, щодо якого особа має право чи зацікавленість. Цей термін не містить базовий актив або зобов'язання, якщо цей актив або зобов'язання самі по собі не є електронним записом. Зазначені визначення отримали свою формалізацію у чинних нормативних актах. Водночас варто звернути увагу зокрема і на визначення, що закріплені у проектах деяких Законів. Так, у Проекті Закону України № 9083-1 [23] віртуальні активи визначаються як токени і криптовалюта. Цей підхід до визначення цифрового активу можна позначити як вузький, криптоорієнтований підхід.

Сапожков О. та Крючкова Е. [11] уточнюють, що як права 3 бездокументарних цінних паперів, так і частки у статутному капіталі суб'єктів господарювання можуть бути посвідчені електронними даними - “цифровими правами". Зі свого боку сукупність відповідних прав, закріплених за конкретною особою, вже детермінується “цифровим фінансовим активом”.

Арянова Т. [10] говорить про три основні типи цифрового активу, до яких належать: а) формальні - повністю централізовані та можуть позначатися як такі, що переносять вартість лише формально; б) криптовалюти - повністю децентралізовані; в) гібридні - окремі елементи інфраструктури цих активів централізовані, притому що інші децентралізовані або ж взагалі не існують.

Це свідчить, що утворився розподіл у використанні цього поняття у сфері інформаційних технологій і в економіко-правовій сфері. Незважаючи на поверхневу схожість суті цифрового активу 3 наведеними вище явищами, єдині критерії, що повністю описують його природу та властивості, відсутні.

Проаналізувавши вищенаведені підходи щодо поняття “цифровий актив”, можна констатувати, що сьогодні у суспільстві відбувається підміна понять, де частіше за все цим терміном називають криптовалюту. Такі тенденції можна співвіднести із достатньо неоднозначним статусом криптовалют i, як наслідок, 
спробами мінімізувати негативне ставлення до феномена, що вивчається.

Отже, проаналізовано наукові публікації та дослідження 3 питання тлумачення поняття цифрового активу. Досліджена сутність поняття “цифровий актив" на підставі етимологічного аналізу. Запропоноване поняття враховує сутнісно-смислові особливості досліджуваного феномена; характеризується чотирма складовими: економічною, правовою, інформаційною, ціннісною. Це дозволило обгрунтувати сутність поняття “цифровий актив”, виокремити особливості використання цього поняття, а також уточнити взаємозв'язок і взаємозалежність між його складовими. 


\section{РОЗДІЛ 3. ВПЛИВ ЦИФРОВИХ АКТИВІВ НА СОЦІАЛЬНО-ЕКОНОМІЧНИЙ РОЗВИТОК ТА РОЛЬ ПРОГНОЗУВАННЯ В УМОВАХ АНТИМОНОПОЛІЗАЦІЇ ЕКОНОМІКИ}

На сучасному етапі соціально-економічний розвиток країн світу зазнає все більшого впливу від процесів цифровізації, які змінюють підходи вирішення проблем на різних рівнях і в різних сферах життя. Вони в основному спрямовані на пошук нових можливостей для підвищення добробуту та вирішення нагальних соціальних проблем: від охорони здоров'я, освіти та навколишнього середовища.

В аспекті посилення та загострення проблем соціальноекономічного розвитку національної економіки постає питання пошуку результативної моделі державного управління економіки в Україні, однією з ключових функцій якої $є$ прогнозування. Така проблематика $\epsilon$ актуальною також 3 огляду на посилення проблем монополізації національних ринків, згортання малого та середнього бізнесу. Антимонопольна політика держави, функціонування іiі інституцій та сама система антимонопольного регулювання економіки потребують детального дослідження функції прогнозування, iii ролі та значення при формуванні антимонопольної політики держави.

Основним завданням при прогнозуванні соціальноекономічного розвитку економіки $\epsilon$ визначення кількісних параметрів та показників щодо розвитку економічної системи в майбутньому. Існує два типи прогнозів:

- загальні економічні прогнози розвитку економічної системи в цілому;

- прогнози розвитку окремих галузей та сфер регіональної економіки. Загальні економічні прогнози - це розробка майбутніх сценаріїв розвитку, яка повинна базуватися на можливих майбутніх ситуаціях.

В рамках загального економічного прогнозу слід визначити найбільш загальні показники, які можуть бути орієнтирами для подальшого розвитку. 
Ці дані можуть бути інформаційною основою для прогнозування розвитку окремих підрозділів регіональної системи.

Важливою особливістю прогнозування соціальноекономічного розвитку є необхідність прогнозування регіонального розвитку не лише як незалежної системи, але і як частини національної економіки. Довгострокові прогнози особливо важливі в управлінні національною економікою та розвитку регіональних соціально-економічних систем. Збільшення ролі довгострокових прогнозів $є$ результатом умов формування ринкової економіки, непослідовність і найголовніше, відсутність цих процесів не сприяє зростанню економіки.

Прогнозування соціально-економічного розвитку економіки не $є$ новим питанням для вітчизняної наукової думки. Такі науковці, як Грабовецький Б. С. [57], Стельмащук А. М. [58], Швайка Л. А. [59], Дикань Н. В. [60] та інші займалися вирішенням проблем суті, методів, інструментарію прогнозування.

Проте, незважаючи на вищенаведене, недостатньо дослідженим $\epsilon$ питання ролі та значення прогнозування в антимонопольному регулюванні економічних процесів та прогнозування впливу цифрових активів на соціально-економічний розвиток.

Необхідним є визначення суті, ролі та значення прогнозування соціально-економічного розвитку для національної економіки України, передусім в антимонопольній сфері діяльності держави.

Теоретичною базою дослідження виступають наукові роботи зарубіжних та вітчизняних вчених. Для досягнення поставленої мети було використано наступні методи дослідження:

- системний підхід;

- метод аналізу та синтезу;

- структурно-логічний аналіз;

- прийоми логічного узагальнення.

Прогнозування займає чільне місце в системі функцій державного управління. Антимонопольна політика держави, іiі результативність, ефект, що можливий від застосування певних іiі інструментів - питання, що знаходяться в площині прогнозування. 
Прогнозування - багатоаспектне явище, воно знаходиться на перетині наук, тому досліджується не тільки в економіці, а й в політиці, соціології та інших науках. Повсякчас прогнозування розглядається поруч та у взаємозв язку 3 плануванням як нерозривні та змістовно взаємозалежні державницькі функції. В даному дослідженні необхідним $\epsilon$ економічне прогнозування антимонопольного регулювання економіки в умовах цифровізації економіки.

В системі державного антимонопольного регулювання функція прогнозування також займає чільне місце. Пріоритетним напрямом розвитку системи антимонопольного регулювання $\epsilon$ зміна загальної концепції такого регулювання та запровадження європейської моделі антимонопольної політики. Проте можна впевнено стверджувати про необхідність уточнення теоретичних засад системи антимонопольного регулювання та побудови іiі структури з урахуванням функції прогнозування.

Доцільним, на наш погляд, $є$ розгляд та дослідження суті прогнозування. Науковець Грабовецький Б. С. $\left[\begin{array}{lll}57, & \text { с. 6] }\end{array}\right.$ прогнозування (від грец. - знання наперед) розуміє як процес формування прогнозів на основі аналізу тенденції й закономірностей розвитку об'єкту (процесу).

Стельмащук А. М. прогнозування розглядає як наукове, обгрунтоване системою встановлення причинно-наслідкових зв'язків і закономірностей, виявлення стану та вірогідних шляхів розвитку явищ і процесів [58].

Швайка Л. А. розглядає прогнозування як певну сукупність способів та прийомів мислення, які використовуються на основі внутрішніх та зовнішніх змін об'єкта прогнозування для виявлення можливих результатів змін [59].

Загалом, при дослідженні терміну “прогнозування” в економічній науці можна виділити два підходи в його розумінні.

1) Підхід до поняття прогнозування як до певного процесу (процесний) (Грабовецький Б. С., Кореєва Е. Б.); 
2) Системний підхід до поняття прогнозування, розуміння прогнозування як певної системи складових (Швайка Л. А. та інші).

Надалі під прогнозуванням впливу цифрових активів на соціально-економічний розвиток в умовах антимонопольного регулювання ринку будемо розуміти процес розробки прогнозів на основі даних про об єкт регулювання. Отже, прогнозування антимонопольного регулювання економіки в Україні в умовах цифровізації економіки має базуватись на основі певних фактичних даних, їх дослідженні та взаємозв'язку.

В науковій літературі існує велика кількість методів економічного прогнозування. При виборі певного методу прогнозування необхідна орієнтація в наявних методах, відбір найбільш актуальних та достовірних методів. 3 цього боку необхідно виділити певні критерії відбору методів прогнозування, що залежать від специфіки об єкта дослідження.

Слід погодитися також й 3 науковцями Дикань Н. В., Борисенко I. I. у праці [60], які розподіляють всі методи прогнозування на три групи:

- неформальні, кількісні та якісні, відносячи до першої, всі види неформальної інформації, яка надходить до суб'єкту управління ззовні;

- розрахункові методи, на основі яких розробляються прогнози, засновані на внутрішній інформації та статистичних даних;

- методи, які застосовується, на думку дослідників, у випадках, коли кількісні методи занадто дорого коштують або ж інформація, що надходить не повна. В найбільш загальному описі це метод експертних оцінок фахівців певної галузі народного господарювання.

Система державного антимонопольного регулювання економіки включає в себе усі державницькі функції, до яких входить й прогнозування антимонопольної діяльності державних органів, прогнозування поведінки монополіста, споживачів та інші.

Принципи, на яких будується система антимонопольного регулювання економіки, наведено в таблиці 1. 
Таблиця 1. Принципи побудови системи антимонопольного регулювання економіки.

\begin{tabular}{|c|c|}
\hline Принцип & Характеристика \\
\hline $\begin{array}{l}\text { Принцип } \\
\text { системності }\end{array}$ & 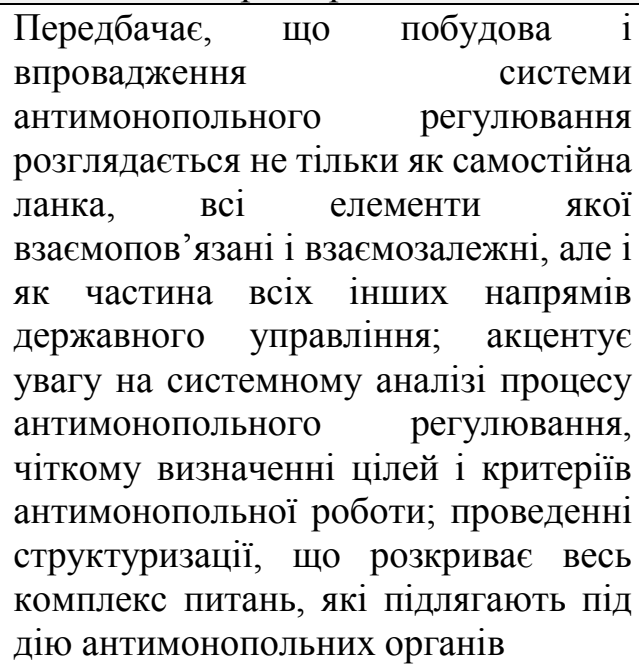 \\
\hline $\begin{array}{l}\text { Принцип } \\
\text { цілеспрямованості }\end{array}$ & 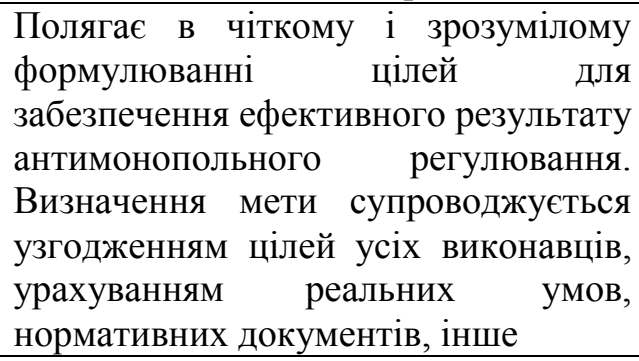 \\
\hline $\begin{array}{l}\text { Принцип } \\
\text { науковості }\end{array}$ & $\begin{array}{l}\text { Орієнтує на управління } 3 \text { наукових } \\
\text { позицій, що потребує від керівників } \\
\text { оволодіння теоретичними основами } \\
\text { організації діяльності, прийняття } \\
\text { управлінського рішення і його } \\
\text { реалізації, усвідомлення і аналізу } \\
\text { одержаних результатів; урахування } \\
\text { суб'єктами управління досягнень } \\
\text { антимонопольного регулювання }\end{array}$ \\
\hline
\end{tabular}




\begin{tabular}{|l|l|}
\hline \multicolumn{1}{|c|}{ Принцип } & \multicolumn{3}{|c|}{ Характеристика } \\
\hline Принцип & Спрямовує на те, що система \\
концептуальності & антимонопольного регулювання \\
& повинна грунтуватися на чітко \\
& визначених положеннях системі \\
& поглядів на дану діяльність що \\
& забезпечить єдність і логічну \\
& несуперечливість підходів в іï \\
& організації та оцінці \\
\hline Принцип & Передбачає внутрішній взаємозв'язок \\
комплексності & усіх видів антимонопольного \\
& регулювання і дає можливість \\
& перебороти с однобічність \\
& функціоналізм с \\
& антимонопольного регулювання \\
\hline
\end{tabular}

Таким чином, визначені принципи повинні стати основою діяльності щодо антимонопольного регулювання, а також $є$ основоположними при побудові системи антимонопольного регулювання в умовах цифровізації економіки.

Прогнозування як i будь-який економічний процес будується на основі певних методик та має певну організаційну структуру, етапність. В працях багатьох науковців пропонуються схеми етапності проведення процесу прогнозування. При цьому, на наш погляд, процес прогнозування доцільно розглядати в контексті нерозривності його організаційно-методичного забезпечення. Організаційно-методичне забезпечення процесу прогнозування запропоновано на рисунку 1.

Отже, при проведенні прогнозування антимонопольної діяльності держави необхідно враховувати його організаційнометодичне забезпечення, володіти необхідною інформацією про конкурентну ситуацію на національних ринках. 
Організаційно-методичні засади процесу прогнозування

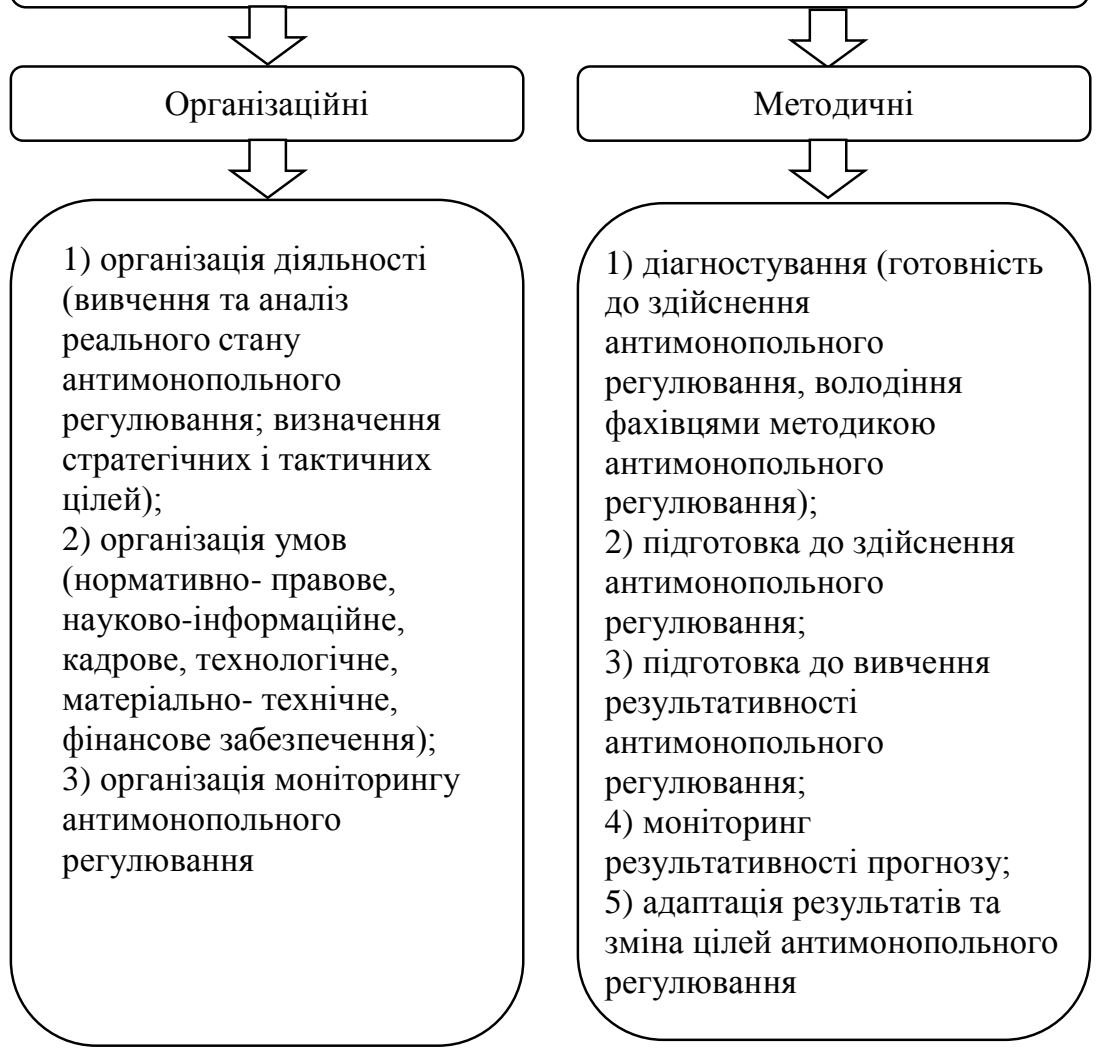

Рисунок 1. Складові організаційно-методичних засад процесу прогнозування антимонопольного регулювання економіки в умовах цифровізації економіки.

Структурні передумови конкуренції в різних галузях економіки формуються за рахунок врахування певних факторів. Зокрема суттєво на них впливають особливості функціонування кожної окремої галузі. Особливості функціонування кожної 3 галузей обумовлюють створення та функціонування відповідної структури ринку. 
Для більш детального аналізу різних ринків та особливостей ïx функціонування, опираючись на економічні показники функціонування різних галузей економіки було проведено кластерний аналіз цих галузей.

Вихідні дані для 2018 року представлено у таблиці 2.

За результатами кластерного аналізу галузі економіки було поділено на 5 кластерів, які представлено у таблиці 3.

Для зручності, кожній з галузей економіки було присвоєно свій порядковий номер, відповідно до їх порядкового номеру у таблиці 3. Дана класифікація та роздрібнення на кластери різних галузей економіки відбувалася через аналіз дендрограми, отриманої за рахунок використання пакету аналізу "Статистика". Дендрограму представлено на рисунку 2.

Tree Diagram for 16 Cases Single Linkage

Euclidean distances

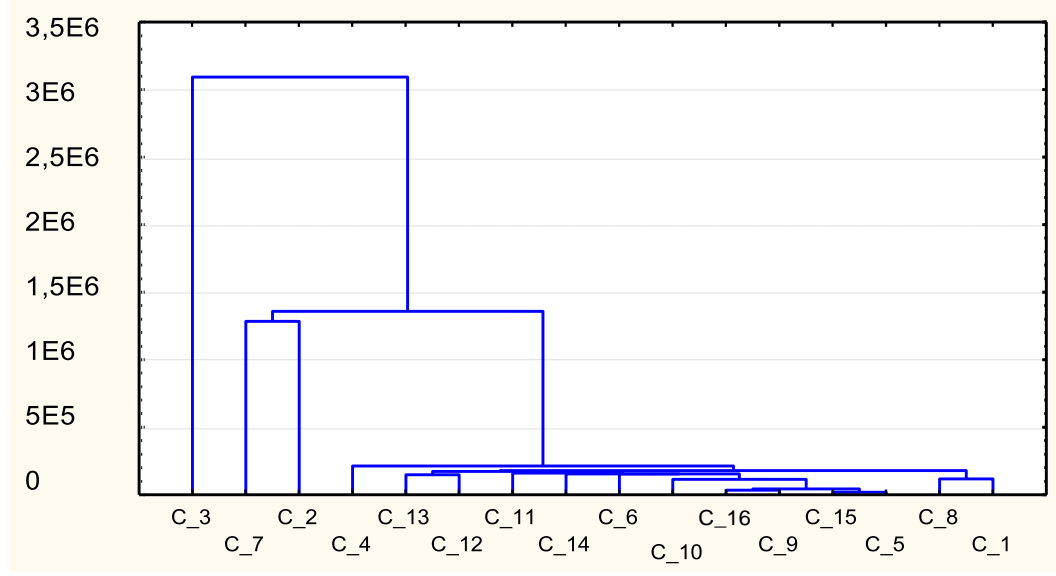

Рисунок 2. Діаграма результатів кластерного аналізу за 16 галузями економіки. 


\begin{tabular}{|c|c|c|c|c|c|c|c|c|}
\hline 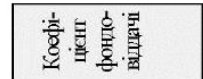 & $\underset{f}{\mp}$ & $\begin{array}{l}尺 \\
\stackrel{8}{\circ}\end{array}$ & $\underset{\exists}{\stackrel{J}{J}}$ & הิ & $\stackrel{8}{-}$ & $\vec{b}$ & $\begin{array}{l}\text { \&े } \\
=\end{array}$ & $\vec{m}$ \\
\hline 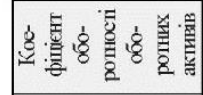 & $\stackrel{9}{=}$ & $\stackrel{\Xi}{F}$ & $\stackrel{2}{=}$ & $\hat{\pi}$ & $\stackrel{\vec{n}}{-}$ & वे & ત্ & $\underset{v}{\Delta}$ \\
\hline$\stackrel{5}{\circ}$ & $\stackrel{\mathbb{N}}{\pi}$ & 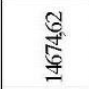 & $\begin{array}{l}n \\
\hat{\infty} \\
\infty \\
n \\
m\end{array}$ & 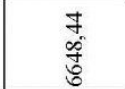 & $\underset{⿱ 宀}{\overrightarrow{5}}$ & 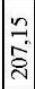 & $\begin{array}{l}\mathscr{D} \\
\text { i } \\
\text { r }\end{array}$ & ? \\
\hline 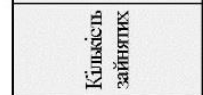 & 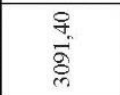 & $\begin{array}{l}\ddot{\infty} \\
\stackrel{8}{0} \\
\varrho\end{array}$ & 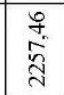 & $\begin{array}{l}\text { है } \\
\text { की }\end{array}$ & $\begin{array}{l}\text { है } \\
\text { ते }\end{array}$ & 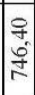 & $\begin{array}{l}R \\
2 \\
2 \\
8 \\
\text { ñ }\end{array}$ & 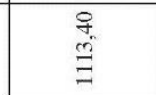 \\
\hline 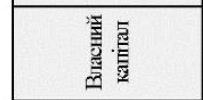 & $\begin{array}{l}\text { \& } \\
\text { కू } \\
\text { gे }\end{array}$ & हू & $\begin{array}{l}5 \\
\frac{5}{7} \\
7 \\
3\end{array}$ & $\begin{array}{l}\text { : } \\
\text { in } \\
\text { a }\end{array}$ & $\begin{array}{l}\text { 总 } \\
\text { in } \\
\text { a }\end{array}$ & 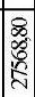 & 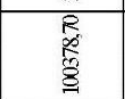 & $\begin{array}{l}\bar{\pi}_{2} \\
\text { है } \\
\vdots\end{array}$ \\
\hline 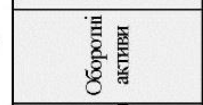 & $\begin{array}{l}\text { 孚 } \\
\frac{1}{*} \\
\stackrel{0}{0}\end{array}$ & 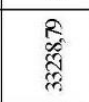 & $\begin{array}{l}2 \\
\frac{8}{8} \\
\frac{8}{2}\end{array}$ & 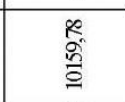 & 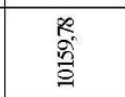 & 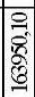 & 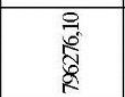 & $\begin{array}{l}\text { 离 } \\
\text { 总 }\end{array}$ \\
\hline 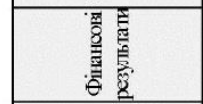 & $\begin{array}{l}\text { P } \\
\text { E⿱ } \\
\text { ה }\end{array}$ & $\begin{array}{l}\frac{9}{3} \\
\frac{3}{1} \\
\end{array}$ & 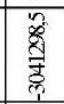 & $\frac{8}{8}$ & 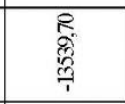 & 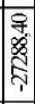 & $\begin{array}{l}\mathscr{8} \\
\mathbb{0} \\
\frac{0}{8} \\
1 \\
\end{array}$ & $\begin{array}{l}8 \\
8 \\
5 \\
1\end{array}$ \\
\hline 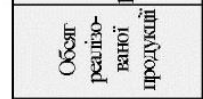 & 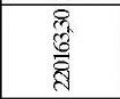 & 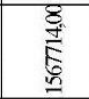 & 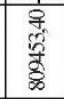 & $\begin{array}{l}8 \\
\frac{8}{8} \\
\frac{8}{2}\end{array}$ & $\begin{array}{l}8 \\
8 \\
8 \\
0 \\
2\end{array}$ & 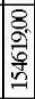 & 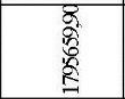 & 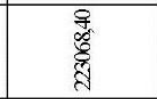 \\
\hline 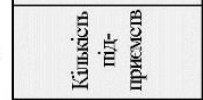 & 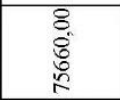 & $\begin{array}{l}8 \\
\ddot{1} \\
0 \\
0\end{array}$ & $\begin{array}{l}8 \\
8 \\
20 \\
\frac{\pi}{2}\end{array}$ & $\begin{array}{l}8 \\
\overleftarrow{0} \\
i\end{array}$ & $\underset{8}{8}$ & 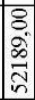 & $\begin{array}{l}8 \\
\text { d: } \\
\text { s. } \\
\text { s }\end{array}$ & 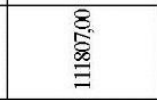 \\
\hline$\stackrel{\vec{m}}{\cdots}$ & 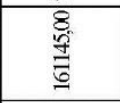 & $\frac{8}{8}$ & $\begin{array}{l}8 \\
\text { 8. } \\
\text { के } \\
\text { वे }\end{array}$ & $\begin{array}{l}8 \\
8 \\
60 \\
80 \\
7 \\
7\end{array}$ & $\begin{array}{l}8 \\
8 \\
0 \\
0 \\
\end{array}$ & \begin{tabular}{|c|}
8 \\
0 \\
0 \\
0 \\
0 \\
0 \\
n.
\end{tabular} & है & $\begin{array}{l}8 \\
8 \\
\text { \& } \\
8\end{array}$ \\
\hline 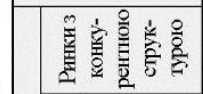 & 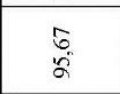 & \&. & 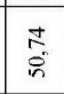 & 8 & $\stackrel{8}{\circ}$ & 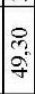 & 文 & है \\
\hline 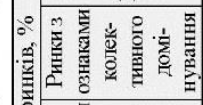 & $\stackrel{m}{2}$ & $\begin{array}{l}n \\
8 \\
8\end{array}$ & $\begin{array}{l}\text { ¿े } \\
\text { ते }\end{array}$ & 8 & $\stackrel{8}{\circ}$ & 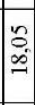 & 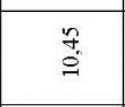 & $\begin{array}{l}\infty \\
\infty \\
\Leftrightarrow\end{array}$ \\
\hline 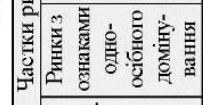 & $\underset{i}{\text { i }}$ & $\begin{array}{l}\text { 吉 } \\
\stackrel{5}{f}\end{array}$ & $\begin{array}{l}8 \\
\text { in }\end{array}$ & $\begin{array}{l}\tilde{0} \\
\hat{8}\end{array}$ & $\begin{array}{l}\text { 足 } \\
\text { r }\end{array}$ & $\begin{array}{l}8 \\
\text { âd }\end{array}$ & वे & $\begin{array}{l}\infty \\
\grave{m} \\
\stackrel{m}{2}\end{array}$ \\
\hline 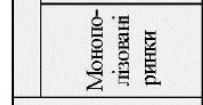 & สู & กี & $\approx$ & $\stackrel{\infty}{\stackrel{\infty}{+\infty}}$ & $\frac{0}{8}$ & $\begin{array}{l}\text { to } \\
\stackrel{-}{0}\end{array}$ & $\stackrel{\infty}{n}$ & $\underset{n}{\stackrel{5}{n}}$ \\
\hline 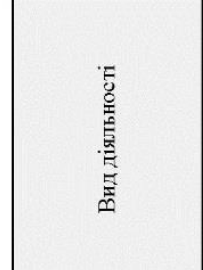 & 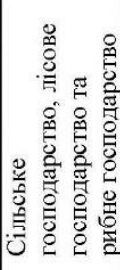 & 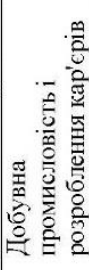 & 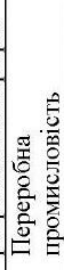 & 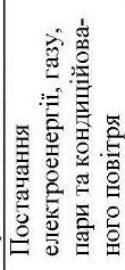 & 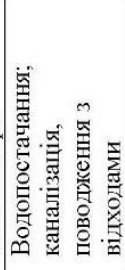 & 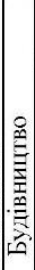 & 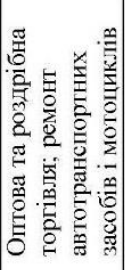 & 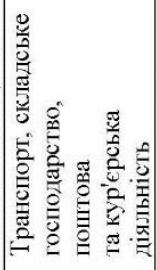 \\
\hline
\end{tabular}




\begin{tabular}{|c|c|c|c|c|c|c|c|c|}
\hline 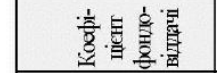 & i⿱ & $\begin{array}{c}\infty \\
\infty \\
\tilde{m}^{\prime}\end{array}$ & $\begin{array}{l}o \\
\substack{0 \\
0 \\
0}\end{array}$ & $\begin{array}{l}g \\
g_{0}\end{array}$ & $\therefore$ & त્वे & 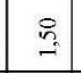 & 8 \\
\hline 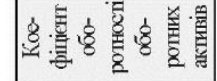 & ڤे & 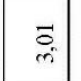 & בֶ: & $\begin{array}{l}0 \\
0 \\
0 \\
0\end{array}$ & $\begin{array}{l}8 \\
: \\
0\end{array}$ & $\vec{I}$ & $\vec{i}$ & 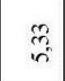 \\
\hline g & ले & $\begin{array}{l}\stackrel{9}{\vec{n}} \\
\stackrel{m}{n}\end{array}$ & $\begin{array}{l}0 \\
\stackrel{2}{0} \\
\stackrel{2}{0}\end{array}$ & 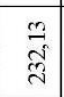 & 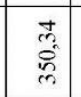 & ه. & 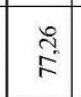 & בి \\
\hline & 高 & 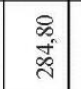 & 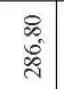 & 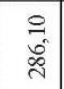 & \begin{tabular}{l|l}
8 \\
0 \\
$\vdots$ \\
$\vdots$
\end{tabular} & 帝 & 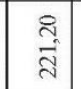 & 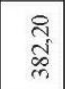 \\
\hline & 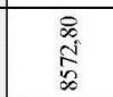 & $\begin{array}{l}\infty \\
\stackrel{\vec{Z}}{\mathrm{~A}}\end{array}$ & 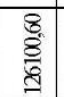 & : & $\begin{array}{l}8 \\
8 \\
\frac{6}{8} \\
\end{array}$ & 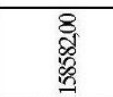 & $\begin{array}{l}8 \\
\vec{g} \\
=\end{array}$ & \begin{tabular}{|c|}
8 \\
08 \\
0 \\
0
\end{tabular} \\
\hline 8 & 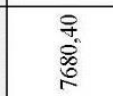 & \begin{tabular}{l|l}
8 \\
0 \\
0 \\
0
\end{tabular} & 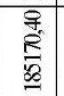 & $\begin{array}{l}\text { 要 } \\
\text { 至 } \\
\end{array}$ & 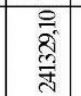 & 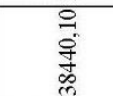 & 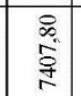 & \begin{tabular}{|l|l} 
\\
2 \\
0 \\
0
\end{tabular} \\
\hline & $\begin{array}{l}8 \\
8 \\
0 \\
\vdots \\
1 \\
1\end{array}$ & 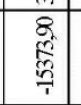 & 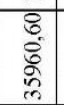 & 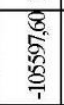 & $\begin{array}{l}0 \\
\text { 荌 } \\
\end{array}$ & 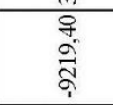 & 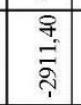 & 象 \\
\hline 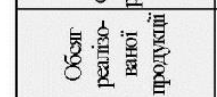 & 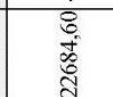 & 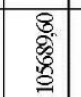 & 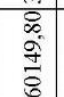 & 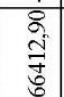 & \begin{tabular}{l|l}
9 \\
6 \\
6 \\
0 \\
2
\end{tabular} & 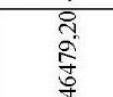 & 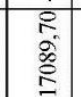 & \begin{tabular}{|l|}
8 \\
0 \\
0 \\
0 \\
0 \\
\end{tabular} \\
\hline 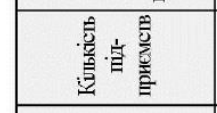 & 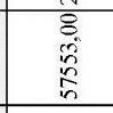 & 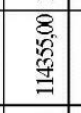 & 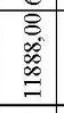 & 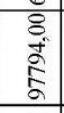 & 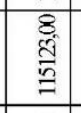 & $\begin{array}{l}8 \\
\text { 寺 } \\
\end{array}$ & $\begin{array}{l} \\
0 \\
0 \\
0 \\
0\end{array}$ & \begin{tabular}{|l|} 
\\
\\
0 \\
0 \\
0 \\
\end{tabular} \\
\hline 啚 & $\begin{array}{l}8 \\
\text { ते } \\
\text { Sू }\end{array}$ & 竎 & 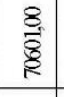 & $\begin{array}{l}8 \\
\frac{8}{3} \\
\end{array}$ & $\begin{array}{l}8 \\
\text { o. } \\
\text { है } \\
\end{array}$ & $\begin{array}{l}8 \\
\\
\\
\end{array}$ & 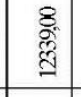 & \begin{tabular}{|l}
8 \\
8 \\
嵒 \\
\end{tabular} \\
\hline 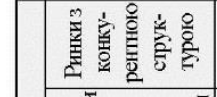 & స్ & $\vec{~}$ & $\stackrel{\stackrel{2}{2}}{=}$ & \begin{tabular}{l|l|}
+ \\
के \\
$\infty$
\end{tabular} & $\begin{array}{l}3 \\
\vdots \\
a \\
a\end{array}$ & 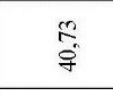 & 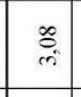 & \begin{tabular}{l|}
$\infty$ \\
0 \\
iे \\
\end{tabular} \\
\hline & ूे & E & $\begin{array}{l}\infty \\
\stackrel{\infty}{2}\end{array}$ & 恖 & $\begin{array}{l}8 \\
\text { in }\end{array}$ & बे & $\stackrel{\infty}{\rightarrow}$ & $\stackrel{0}{=}$ \\
\hline 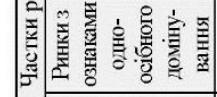 & $\begin{array}{l}8 \\
6 \\
\end{array}$ & 8 & $\begin{array}{l}\infty \\
\substack{0 \\
0} \\
\end{array}$ & $\begin{array}{l}0 \\
\stackrel{0}{0}\end{array}$ & 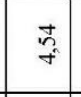 & $\begin{array}{l}8 \\
\text { f } \\
\end{array}$ & ते & $\begin{array}{c}8 \\
\text { in } \\
\end{array}$ \\
\hline 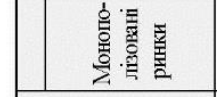 & $\frac{n}{0}$ & $\stackrel{\infty}{0}$ & $\stackrel{\circ}{g}$ & 鹿 & $\begin{array}{l}9 \\
\text { i } \\
4\end{array}$ & $\underset{c}{F}$ & $\begin{array}{l}\overrightarrow{\sigma_{0}} \\
\Leftrightarrow\end{array}$ & {$\left[\begin{array}{l}n \\
\infty \\
\infty\end{array}\right.$} \\
\hline 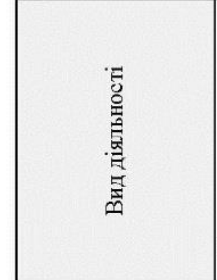 & 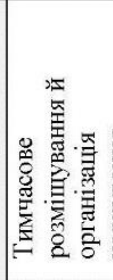 & 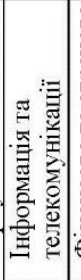 & & & 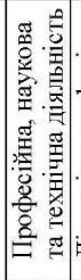 & 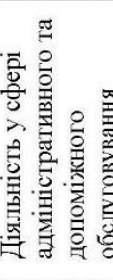 & 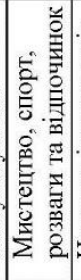 & 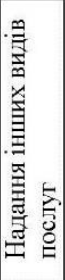 \\
\hline
\end{tabular}




\begin{tabular}{|c|c|c|c|c|c|}
\hline 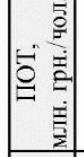 & 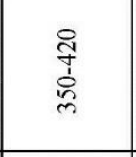 & $\begin{array}{l}8 \\
8 \\
\frac{0}{2} \\
\\
\end{array}$ & 令 & 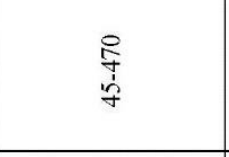 & $\begin{array}{l}8 \\
8 \\
\\
\frac{1}{8} \\
\text { ํ. }\end{array}$ \\
\hline 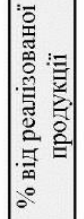 & ஸิ & $\ddot{n}$ & $\frac{\infty}{\dot{m}}$ & $\begin{array}{l}\text { L̊̀ } \\
\stackrel{\leftrightarrow}{0}\end{array}$ & $\stackrel{p}{o}$ \\
\hline 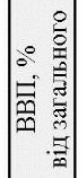 & $\begin{array}{l}\text { ஸे } \\
\stackrel{2}{n}\end{array}$ & 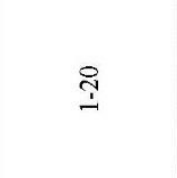 & $\frac{n}{\dot{m}}$ & $\stackrel{I}{I}$ & $\begin{array}{l}\infty \\
\stackrel{1}{1} \\
\text { م. } \\
0\end{array}$ \\
\hline 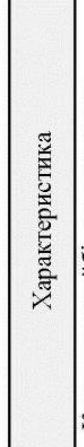 & 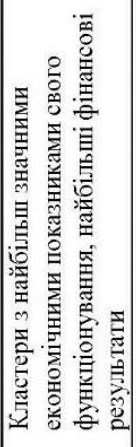 & 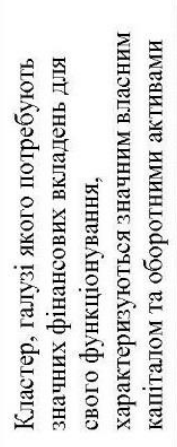 & 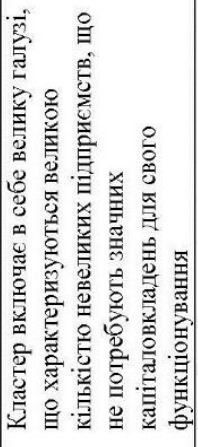 & 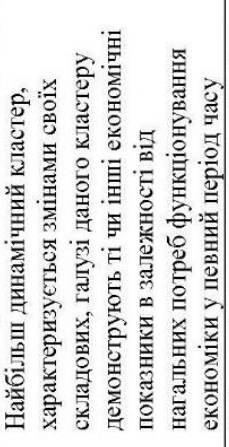 & 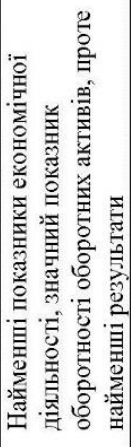 \\
\hline$\frac{\infty}{\stackrel{\sim}{*}}$ & $m$ & in & $\begin{array}{l}m \\
\infty \\
0 \\
0\end{array}$ & 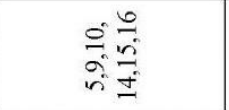 & ナ \\
\hline 궁 & $r$ & $\begin{array}{l}0 \\
\underset{i}{*}\end{array}$ & $m$ & $\begin{array}{l}= \\
= \\
\infty \\
=\end{array}$ & 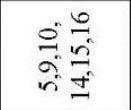 \\
\hline$\stackrel{\circ}{\circ}$ & r & $m$ & $\begin{array}{l}\infty \\
0 \\
0 \\
-1\end{array}$ & $\frac{ \pm}{\simeq}$ & 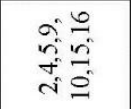 \\
\hline 竞 & - & $N$ & $m$ & + & $n$ \\
\hline
\end{tabular}


3 таблиці видно, що велика кількість галузей групуються в один кластер і серед усіх присутні галузі, що явно відрізняються від усіх інших галузей. Протягом всього аналізованого періоду серед галузей можна виділити 7, 3, 2 та 4 галузь, яким відповідають "Оптова та роздрібна торгівля; ремонт автотранспортних засобів і мотоциклів (7)”, “Переробна промисловість (3)”, “Добувна промисловість і розроблення кар'єрів (2)” та “Постачання електроенергії, газу, пари та кондиційованого повітря (4)”. Ці галузі суттєво відрізняються від інших галузей, про що свідчать значні відстані між даними галузями у кластерному аналізі та іншими галузями.

Кластерні злиття - це один із способів, що дозволяє організувати інноваційні процеси усіх комплексів, завдяки якому не лише окремі компанії вступають у конкурентну боротьбу, а декілька компаній, i, як наслідок, зменшують собівартість продукції в результаті спільної технологічної співпраці. Злиття в кластери створюють особливий економічний простір для покращення умов для вільної торгівлі, вільного руху капіталу та людських ресурсів.

Кластери в економіці - це модель конкурентоспроможної та сприятливої для інвестицій економіки, яка спрямована на досягнення високого рівня та якості життя населення.

Необхідність кластерів полягає у тому, що:

- інноваційні процеси часто вимагають ресурсів та компетенції, які мають місце поза межами однієї компанії;

- кластери: поєднання конкуренції та співпраці;

- кластери $є$ частиною більш широкої концепції конкурентоспроможності;

- кластерні об'єднання або об'єднання місцевих регіональних виробничих систем сприяють економічному зростанню регіонів.

Метод кластеризації використовують:

- для аналізу конкурентоспроможності;

- для забезпечення соціально-економічного розвитку;

- для розробки стратегій розвитку економіки;

- для забезпечення інноваційної політики;

- як основа для великої та малої ділової взаємодії.

Основною метою кластеризації є підвищення внутрішньої та 
міжнародної конкурентоспроможності його членів шляхом комерційної та некомерційної співпраці, досліджень та інновацій, освіти, навчання та підтримки.

Позитивними рисами взаємодії кластера:

- підвищення результативності виробництва;

- ефективна інноваційна політика;

- забезпечення доступу до спеціалізованих постачальників, послуг, кваліфікованої робочої сили, технологічних знань;

- більша гнучкість та масштабний вплив;

- спільна діяльність;

- колективна ефективність.

Недоліками кластерної взаємодії можуть бути:

- фізична інфраструктура;

- відсутність наявного капіталу;

- віддаленість регіонів;

- недостатня кількість робочої сили, яка має кваліфікацію.

Таким чином, розділення галузей економіки на кластери дає змогу більш детально проаналізувати особливості функціонування кожної з галузей окремо.

Особливості функціонування безумовно впливають на загальну конкурентну ситуацію кожного 3 ринків, отримані кластери дають змогу зрозуміти причини структурних передумов функціонування конкуренції на різних ринках, опираючись на економічні показники, результати діяльності різних галузей, виокремивши їх особливості та ключові характеристики, у тому числі - такі, що визначають вибір інструментарію платежів та перспективи розвитку механізму цифрових активів.

Подальший аналіз має включати в себе аналіз структури ринків, типу ринків, загальної конкурентної ситуації на ринку та процесів, що відбуваються на ньому. Це дасть змогу зрозуміти особливості його розвитку, причини функціонування притаманної йому структури та типу, а також дасть змогу реагувати на його зміни та регулювати його діяльність за даної потреби.

В процесі розвитку цифрових технологій відбувається зміна існуючих постулатів та концепцій економічного розвитку країни. Попередній спосіб виробництва, побудова економіки на промислово-виробничому комплексі відходять у минуле, на 
передній план виходять інформаційно-цифрові активи.

3 цим погоджуються й науковці Наджафов 3., Гусейнова А., які в праці [61, с. 52] виділяють такі основні аспекти розвитку економік країн світу: цифровий, сітьовий, глобальний, стійкий та інноваційний, тим підкреслюючи новітні тенденції розвитку економік в XXI столітті.

Вищезазначене зумовлює появу нових явищ та процесів, відбувається формування понятійно-категорійного апарату інформаційно-цифрової сфери. Так, наприклад, процес цифровізації розглядається в широкому та в вузькому значенні. У вузькому розумінні під цифровізацією науковці Єгоров I. Ю, Рижкова Ю. О. [62, с. 9] розуміють певне перетворення аналогових даних та процесів у цифровий, що робить дані та операції з ними значно продуктивнішими, ніж при використанні аналогових технологій.

У більш широкому розумінні цифровізація - це використання даних та цифрових технологій, а також взаємозв'язок між ними, що призводить до нових або змін існуючих видів діяльності, тоді як цифрова трансформація стосується економічних та суспільних наслідків саме цифровізації [62, с. 9].

Цифрові процеси в економіках країн світу породжують нове поняття в економічній науці - цифрова економіка. На думку Кленіна О. В. [63, с. 44], під цифровою економікою розуміється “система економічних та соціально-культурних відносин, що базуються на використанні цифрових інформаційнокомунікаційних технологій, функціонування якої спрямоване на зростання ефективності суспільного виробництва, підтримку стійких темпів зростання економіки з метою підвищення добробуту та якості життя населення".

Авторське бачення структури та складових цифрової економіки зображено на рисунку 3.

Отже, під цифровою економікою пропонуємо розуміти систему цифрових активів та технологій, що через комунікативну систему взаємодіють зі споживачами, державою та бізнесом для досягнення цілей сталого розвитку країни. 


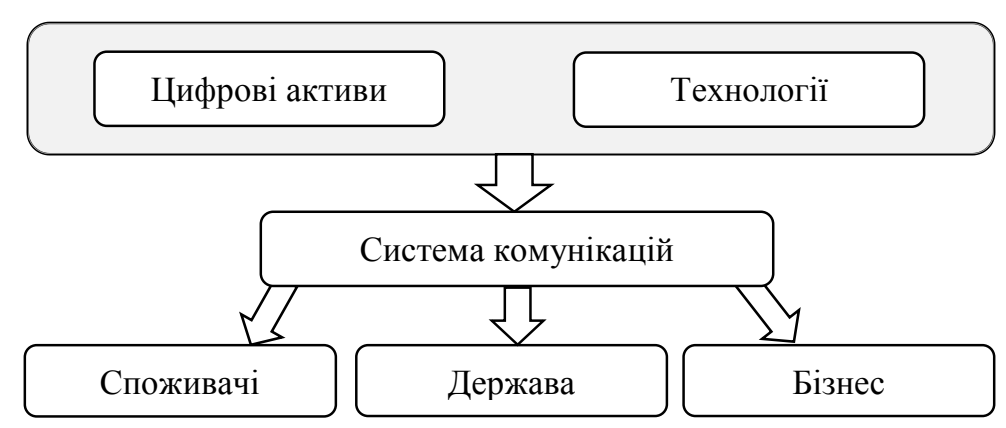

Рисунок 3. Складові системи цифрової економіки.

Процеси цифровізації та впровадження цифрових активів в різні сфери суспільно-економічного розвитку країни породжують нові явища в економіці та прискорюють вже звичні процеси. Ті процеси та методики, які в минулому займали значний проміжок часу, в процесі впровадження цифрових активів прискорюються, автоматизуються.

Конкуренція на ринках та процеси цифровізації досліджуються за допомогою індексу цифрової економіки та суспільства (DESI). Регулярний моніторинг процесів цифровізації економік країн $€$ д дозволяє відстежити тенденції та спрогнозувати розвиток кожної окремої країни за відповідним показником. DESI включає в себе такі показники:

- Зв'язок - розвиток ринку широкосмугового зв'язку в $\mathrm{CC}$;

- Людський капітал - цифрове включення та навички;

- Використання Інтернет-послуг;

- Інтеграція цифрових технологій;

- Цифрові суспільні послуги;

- ІКТ-сектор ЄС та його науково-дослідні роботи;

- Дослідження та інновації: ІКТ-проекти в цифровій програмі “Горизонт 2020" [64].

Зазначені показники в сукупності складають індекс цифрової економіки та суспільства, що дозволяє зрозуміти конкурентоспроможність країн $Є С$ в аспекті цифрового розвитку, вплив цифрових активів на соціально-економічний розвиток (рисунок 4). 


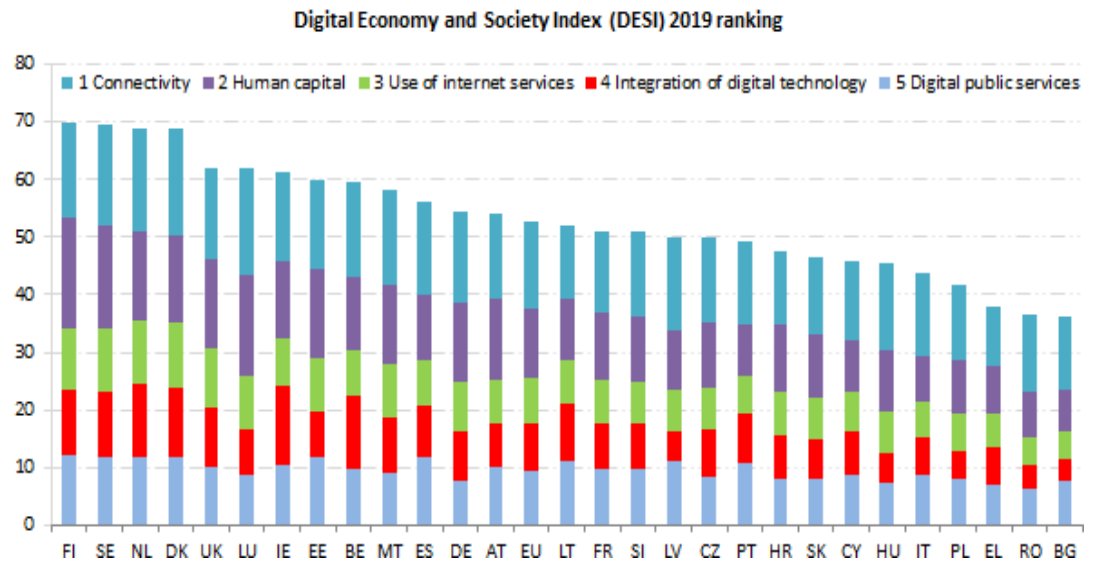

Рисунок 4. Рейтинг країн за складовими індексу цифрової економіки [64].

Вивчення структури ринку, його типу і економічних процесів що відбуваються на ньому пов'язано 3 визначенням стану конкурентного середовища, його оцінкою i дослідженням можливостей обмеження або розвитку конкуренції при впровадженні новітніх технологій здійснення господарської активності, зокрема, пов' язаних із використанням цифрових активів та інших інформаційних продуктів, впровадження яких пов'язано із підвищенням ефективності використання капіталів в напрямку прискорення оборотності коштів та здійснення неготівкових розрахунків, розширення кола джерел залучення інвестиційних ресурсів та ін.

Так, до причин обмеження використання готівки зазвичай відносять високі витрати їх обігу (витрати на виробництво, емісію, організацію обігу, а також витрати, пов'язані із знищенням старих банкнот). Також впливовим фактором $\epsilon$ анонімний характер готівки, який стимулює зростання тіньової економіки. Тому формується припущення, що держава повинна спрямувати свої регуляторні інструменти на розвиток і стимулювання використання безготівкових розрахунків у роздрібній торгівлі. В той же час 
збільшення частки безготівкових розрахунків дає можливість забезпечити значне скорочення терміну проходження платежів, захист від розкрадання, підвищить надійність та ефективність розрахунків, а також прискорить обіг грошових засобів, що дасть можливість банкам використовувати залишки засобів на рахунках клієнтів для кредитування і здійснення інвестицій в економіку країни.

В якості засобів платежу при здійсненні роздрібних операцій сьогодні застосовуються: готівка (банкноти, монети), платіжні банківські картки (кредитні, дебетові), чеки, банківські перекази, а також електронні гроші, природа яких близька до приватних грошей. Кожен засіб платежу має свої особливості, які дозволяють йому займати певне положення на роздрібному платіжному ринку.

Для зручності аналізу пропонується іменувати засобом платежу всі досліджувані засоби обміну, включаючи як засоби платежу (гроші), випущені в обіг Національним банком, так i зобов'язання комерційних банків, та інших інститутів, які використовуються для погашення тих чи інших зобов'язань або проведення операцій купівлі-продажу.

Перш за все необхідно виявити принципові відмінності згаданих засобів платежу:

- готівкові гроші - емітуються центральним банком у вигляді банкнот і монет, розглядаються усіма агентами як законний засіб платежу [65];

- депозитні гроші - різні механізми доступу до банківського рахунку.

Незважаючи на те, що таких механізмів існує досить багато, в рамках даного аналізу розглядаються [66]:

- інтернет-банкінг - механізм управління власним поточним рахунком на основі протоколів взаємодії, визначених банком, i традиційних механізмів клірингу, використовуваних банками або платіжними провайдерами;

- банківські карти (включаючи віртуальні) - механізм доступу до спеціальних рахунків, що відкриваються банком при використанні протоколів взаємодії та клірингу, розвиваються i підтримуються міжнародними та національними платіжними системами; 
- електронні гроші (e-money) - одиниці вартості, які зберігаються на електронному пристрої, приймаються як засіб платежу іншими особами, ніж особа, яка їх випускає, і є грошовим зобов'язанням цієї особи, що виконується в готівковій або безготівковій формі [67; 68].

У свою чергу електронні гроші включають в себе три групи продуктів:

- електронні гаманці - перезавантажувальні багатоцільові передплачені картки, що зберігають електронну вартість, використовувану для здійснення роздрібних платежів [69, с. 376]. Важливо зазначити, що електронні гаманці випускаються в закрито циркулюючих системах, особливістю яких $є$ те, що в них відсутня можливість багаторазових переказів однієї і тієї ж вартості між агентами;

- мережеві гроші - передплачений продукт, який дозволяє використовувати кошти за допомогою спеціального програмного забезпечення. Дане програмне забезпечення може розміщуватися як на комп'ютері користувача, так i на віддаленому сервері, а трансакції відбуваються за допомогою телекомунікаційних мереж (Інтернет тощо);

- мобільні гроші - передплачений продукт, який дозволяє використовувати кошти шляхом контакту телефону і відповідного терміналу, поповнення коштів i оновлення необхідного програмного забезпечення здійснюється по радіоканалу.

Для того щоб виявити, якими конкурентними перевагами володіють ті чи інші платіжні інструменти, необхідно систематизувати базові вимоги (характеристики), які пред'являються до засобу платежу.

При здійсненні аналізу цих вимог були враховані специфічні фактори, що мають значення для емісійних інститутів, комерційних банків, платіжних агентів, продавців, населення та держави.

Важливо зазначити, що згадані інструменти розглядалися лише як засіб платежу; їх властивості як засоби накопичення та заощадження не розглядалися.

Серед базових вимог можуть бути виділені наступні (таблиця 4). 
Таблиця 4. Базові вимоги до засобів платежу (інструментів розрахунку).

\begin{tabular}{|c|c|}
\hline Базові вимоги & Характеристика \\
\hline $\begin{array}{l}\text { Простота } \\
\text { використання }\end{array}$ & $\begin{array}{l}\text { Потрібна для масового розповсюдження } \\
\text { засобів платежу та уникнення складнощів в } \\
\text { ix застосуванні. }\end{array}$ \\
\hline $\begin{array}{l}\text { Технологічність } \\
\text { використання }\end{array}$ & $\begin{array}{l}\text { Необхідність визначається сучасною } \\
\text { трансформацією економіки та переходом до } \\
\text { цифрової економіки. }\end{array}$ \\
\hline $\begin{array}{l}\text { Стійкість до } \\
\text { шахрайства }\end{array}$ & $\begin{array}{l}\text { Засоби платежу можуть бути використані } \\
\text { шахраями за умови іх недостатнього } \\
\text { захисту емітентом, тому потрібна розробка } \\
\text { механізмів захисту засобів платежу. }\end{array}$ \\
\hline Анонімність & $\begin{array}{l}\text { Важлива вимога, так як не всі учасники } \\
\text { ринку засобів платежу бажають бути } \\
\text { ідентифікованими в процесі здійснення } \\
\text { господарських операцій. }\end{array}$ \\
\hline Універсальність & $\begin{array}{l}\text { Дозволяє використовувати засоби платежу в } \\
\text { різноманітних господарських сферах обігу } \\
\text { фінансових інструментів. Зменшення } \\
\text { обмежень на засіб платежу веде до більшого } \\
\text { його поширення. }\end{array}$ \\
\hline Оборотність & $\begin{array}{l}\text { Здатність без спеціального підтвердження } \\
\text { використовуватися як засіб платежу між } \\
\text { будь-якими з існуючих агентів. }\end{array}$ \\
\hline $\begin{array}{l}\text { Забезпечення мікро- } \\
\text { розрахунків }\end{array}$ & $\begin{array}{l}\text { Засіб платежу повинен мати можливість } \\
\text { забезпечити розрахунки } 3 \text { точністю, } \\
\text { передбаченою законом. При цьому } \\
\text { економічні витрати агентів на організацію } \\
\text { такого платежу не повинні позбавляти його } \\
\text { економічного сенсу. }\end{array}$ \\
\hline Автономність & $\begin{array}{l}\text { Доступність засобу платежу без зв'язку з } \\
\text { мережею. }\end{array}$ \\
\hline Портативність & $\begin{array}{l}\text { Означає, що засоби платежу на сучасному } \\
\text { етапі переходять в інші виміри і мають } \\
\text { більше різноманітних сфер застосування та } \\
\text { видів [69]. }\end{array}$ \\
\hline Час використання & $\begin{array}{l}\text { Необхідність чітко визначеного часу та } \\
\text { умов використання засобу платежу або } \\
\text { позачасове використання. }\end{array}$ \\
\hline
\end{tabular}




\begin{tabular}{|c|c|}
\hline Базові вимоги & Характеристика \\
\hline Ліквідність & $\begin{array}{l}\text { Означає не проблематичний обмін засобу } \\
\text { платежу на грошові кошти. }\end{array}$ \\
\hline $\begin{array}{l}\text { Економічно } \\
\text { раціональна вартість } \\
\text { обслуговування } \\
\text { операцій для } \\
\text { учасників } \\
\text { екосистеми }\end{array}$ & $\begin{array}{l}\text { Комплексна величина, що включає: } \\
\text { Для покупця: вартість володіння платіжним } \\
\text { засобом і розмір можливих комісій при } \\
\text { проведенні платіжної операції в зіставленні } \\
\text { з розміром такої операції. } \\
\text { Для продавця (“merchant”): даний показник } \\
\text { включає вартість операції (комісійні } \\
\text { винагороди платіжних систем і фінансових } \\
\text { агентів або витрати, пов'язані з обробкою } \\
\text { готівки тощо), а також вартість } \\
\text { перетворення отриманого засобу платежу в } \\
\text { таку форму, в якій воно може } \\
\text { використовуватися в подальших операціях } \\
\text { (наприклад, витрати на інкасацію) в } \\
\text { зіставленні з розміром таких операцій. } \\
\text { Для Банку: витрати, пов’язані } \\
\text { обслуговуванням та процесуванням обігу } \\
\text { платіжних засобів [69]. }\end{array}$ \\
\hline Додаткова зручність & $\begin{array}{l}\text { Зручність розрахунків в мережі Інтернет. } \\
\text { Можливість планування, обліку та } \\
\text { контролювання особистих витрат. }\end{array}$ \\
\hline Емісійні витрати [9] & 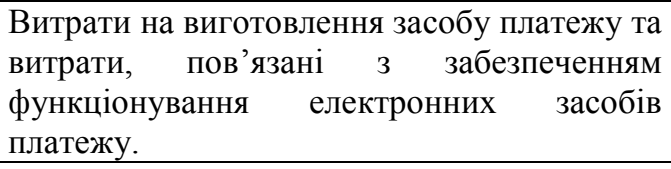 \\
\hline $\begin{array}{l}\text { Можливість } \\
\text { отримання } \\
\text { емісійного доходу }\end{array}$ & $\begin{array}{l}\text { Маються на увазі не комісійні доходи, } \\
\text { пов’язані } 3 \text { платіжними операціями, а } \\
\text { можливість } \\
\text { безпосередньо від етримсї (сеньйораж) абохід від } \\
\text { використання отриманих в якості депозиту } \\
\text { (передоплати) коштів. }\end{array}$ \\
\hline
\end{tabular}

Розглянемо найбільш популярні засоби платежу з точки зору сформульованих базових вимог. В таблиці 5 наведено переваги та недоліки зазначених засобів платежу, що сьогодні використовуються для здійснення роздрібних платежів. 
Таблиця 5. Засоби платежу і тенденції їх розвитку.

\begin{tabular}{|c|c|c|c|}
\hline Засіб & Переваги & Недоліки & Тенденція \\
\hline $\begin{array}{l}\text { Готівкові } \\
\text { гроші }\end{array}$ & $\begin{array}{l}\text { Безкоштовний для } \\
\text { населення, законний } \\
\text { засіб платежу; } \\
\text { простота } \\
\text { розрахунків (для } \\
\text { невеликих сум); } \\
\text { повсюдне } \\
\text { використання; } \\
\text { можливість } \\
\text { розрахунків } \\
\text { “людина - людина” } \\
\text { (далі Р2Р); } \\
\text { можливість } \\
\text { анонімних } \\
\text { розрахунків. }\end{array}$ & $\begin{array}{l}\text { Істотні суспільні } \\
\text { витрати на } \\
\text { готівково- } \\
\text { грошовий обіг; } \\
\text { високий ризик } \\
\text { втрати в } \\
\text { результаті } \\
\text { кримінальних дій } \\
\text { і стихійних лих; } \\
\text { складнощі при } \\
\text { великих } \\
\text { розрахунках; не } \\
\text { пристосовані для } \\
\text { дистанційних } \\
\text { розрахунків в } \\
\text { мережі Інтернет. }\end{array}$ & $\begin{array}{l}\text { Зберігають } \\
\text { нішу } \\
\text { невеликих } \\
\text { платежів; } \\
\text { поступове } \\
\text { витіснення зі } \\
\text { сфери } \\
\text { середніх і } \\
\text { великих } \\
\text { платежів; } \\
\text { поступове } \\
\text { зростання } \\
\text { кількості } \\
\text { транзакцій }\end{array}$ \\
\hline $\begin{array}{l}\text { Дебетові } \\
\text { карти }\end{array}$ & $\begin{array}{l}\text { Зручність } \\
\text { використання, } \\
\text { особливо для } \\
\text { середніх за розміром } \\
\text { платежів; невисока } \\
\text { вартість транзакції } \\
\text { для бізнесу; } \\
\text { можливість } \\
\text { дистанційних } \\
\text { платежів; зниження } \\
\text { ризиків втрати всієї } \\
\text { вартості в результаті } \\
\text { кримінальних дій; } \\
\text { гарантії завершення } \\
\text { платежу від банка- } \\
\text { емітенту картки та } \\
\text { платіжної системи. }\end{array}$ & $\begin{array}{l}\text { Прямо не є } \\
\text { законним } \\
\text { засобом платежу; } \\
\text { наявність витрат } \\
\text { клієнта, } \\
\text { обумовлених } \\
\text { випуском та } \\
\text { використанням } \\
\text { карти; } \\
\text { необхідність } \\
\text { наявності } \\
\text { спеціальної } \\
\text { інфраструктури; } \\
\text { складність } \\
\text { розрахунків Р2Р; } \\
\text { ризики } \\
\text { кримінальних дій } \\
\text { в електронному } \\
\text { середовищі. }\end{array}$ & $\begin{array}{l}\text { Поступове } \\
\text { збільшення } \\
\text { частки на } \\
\text { ринку } \\
\text { платежів; } \\
\text { істотне } \\
\text { зростання } \\
\text { кількості } \\
\text { транзакцій; } \\
\text { розширення } \\
\text { охоплення по } \\
\text { мірі розвитку } \\
\text { інфраструкту- } \\
\text { ри. }\end{array}$ \\
\hline $\begin{array}{l}\text { Кредитні } \\
\text { карти [12] }\end{array}$ & $\begin{array}{l}\text { Зручність } \\
\text { використання; } \\
\text { наявність кредитної }\end{array}$ & $\begin{array}{l}\text { Прямо не } \epsilon \\
\text { законним } \\
\text { засобом платежу; }\end{array}$ & $\begin{array}{l}\text { Поступове } \\
\text { зростання або } \\
\text { стагнація в }\end{array}$ \\
\hline
\end{tabular}




\begin{tabular}{|c|c|c|c|}
\hline Засіб & Переваги & Недоліки & Тенденція \\
\hline & $\begin{array}{l}\text { лінії для клієнта; } \\
\text { стимулювання } \\
\text { покупок; можливість } \\
\text { дистанційних } \\
\text { платежів зниження } \\
\text { ризиків втрати } \\
\text { вартості в результаті } \\
\text { кримінальних дій. }\end{array}$ & $\begin{array}{l}\text { висока вартість з } \\
\text { розрахунку на } \\
\text { одну транзакцію; } \\
\text { витрати на } \\
\text { утримання карти } \\
\text { і необхідність } \\
\text { знань } 3 \\
\text { використання } \\
\text { кредиту; } \\
\text { складність } \\
\text { розрахунків Р2Р; } \\
\text { необхідність } \\
\text { наявності } \\
\text { спеціальної } \\
\text { інфраструктури. }\end{array}$ & $\begin{array}{l}\text { залежності від } \\
\text { насиченості } \\
\text { ринку } \\
\text { кредитування } \\
\text { і розвиненості } \\
\text { інфраструкту- } \\
\text { ри; } \\
\text { розширення } \\
\text { охоплення по } \\
\text { мірі розвитку } \\
\text { інфраструкту- } \\
\text { ри. }\end{array}$ \\
\hline $\begin{array}{l}\text { Перед- } \\
\text { плачені } \\
\text { картки } \\
\text { (елект- } \\
\text { ронні } \\
\text { гроші) }\end{array}$ & $\begin{array}{l}\text { Зручність } \\
\text { використання, в } \\
\text { тому числі для } \\
\text { мікроплатежів; } \\
\text { можливість } \\
\text { дистанційних } \\
\text { платежів; } \\
\text { можливість } \\
\text { здійснити } \\
\text { розрахунки } \\
\text { анонімно; } \\
\text { можливість } \\
\text { розрахунків Р2Р. }\end{array}$ & $\begin{array}{l}\text { Необхідність } \\
\text { наявності } \\
\text { спеціальної } \\
\text { інфраструктури; } \\
\text { висока вартість } \\
\text { транзакціі; } \\
\text { високий ризик } \\
\text { втрати в } \\
\text { результаті } \\
\text { кримінальних дій } \\
\text { і стихійних лих; } \\
\text { обмеження щодо } \\
\text { організації } \\
\text { анонімних } \\
\text { розрахунків до } \\
\text { банків. }\end{array}$ & $\begin{array}{l}\text { Динамічне } \\
\text { зростання і } \\
\text { постійне } \\
\text { збільшення } \\
\text { числа } \\
\text { транзакцій; } \\
\text { обмеження } \\
\text { поширення } \\
\text { сферою } \\
\text { мікроплате- } \\
\text { жів і середніх } \\
\text { платежів. }\end{array}$ \\
\hline $\begin{array}{l}\text { Інтернет- } \\
\text { банкінг } \\
\text { (грошові } \\
\text { перекази) }\end{array}$ & $\begin{array}{l}\text { Низькі ризики; } \\
\text { можливість оплати } \\
\text { великих сум. }\end{array}$ & $\begin{array}{l}\text { Складність } \\
\text { процедури } \\
\text { оплати; } \\
\text { складність } \\
\text { процедури } \\
\text { оплати при } \\
\text { розрахунках Р2P; } \\
\text { висока вартість } \\
\text { транзакції [68]. }\end{array}$ & $\begin{array}{l}\text { Поступове } \\
\text { подальше } \\
\text { скорочення; } \\
\text { збереження } \\
\text { ніші великих } \\
\text { платежів. }\end{array}$ \\
\hline
\end{tabular}


Таким чином, готівкові гроші залишаються найбільш зручним засобом платежу для споживача, завдяки таким ключовим характеристикам як: безкоштовність, повсюдне використання, анонімних розрахунків, простота. Саме тому вони залишаються лідируючим інструментом в розрахунках не тільки в Україні, але і в багатьох країнах, де інфраструктура безготівкових платежів більш розвинена.

Крім того, результати аналізу допомагають пояснити, чому саме банківські (платіжні) карти, будучи досить технологічним способом платежу зможуть скласти конкуренцію готівковим розрахункам у найближчому майбутньому. Такі переваги, як зручність, безпечність та економічність використання, зумовлюють зростання обсягів використання даного інструменту платежу як в світі в цілому, так і в Україні зокрема.

Крім того, аналіз базових вимог до засобів платежу дозволив виділити основні споживчі фактори зростання використання електронних грошей. Основним фактором поширення електронних грошей $\epsilon$ можливість здійснення анонімного платежу (головна перевага готівкових коштів). Звичайно, що вартість послуги електронних грошей у порівнянні 3 іншими засобами платежу є значно вищою. При цьому, споживач готовий доплачувати саме за можливість залишитися анонімним.

Проте дисбаланси та диспропорції, що виникають на фінансовому ринку в результаті впровадження новітніх інформаційних технологій, $€$ проявом i наслідком розбалансованості потреб підтримки цілісності, синхронізації протікання та системної єдності стадій процесу обороту фінансових ресурсів на конкурентних ринках. Для узагальнення характеристик взаємодії різних складових даного процесу за допомогою використання методу побудови канонічних кореляцій доцільним $\epsilon$ визначення характеристик взаємного впливу i залежності між наборами (між 2 списками) канонічних змінних, до складу яких було віднесено такі параметри груп детермінант, які за галузевими сегментами визначають впровадження новітніх інформаційних технологій використання цифрових активів у господарських практиках (рисунок 5). 


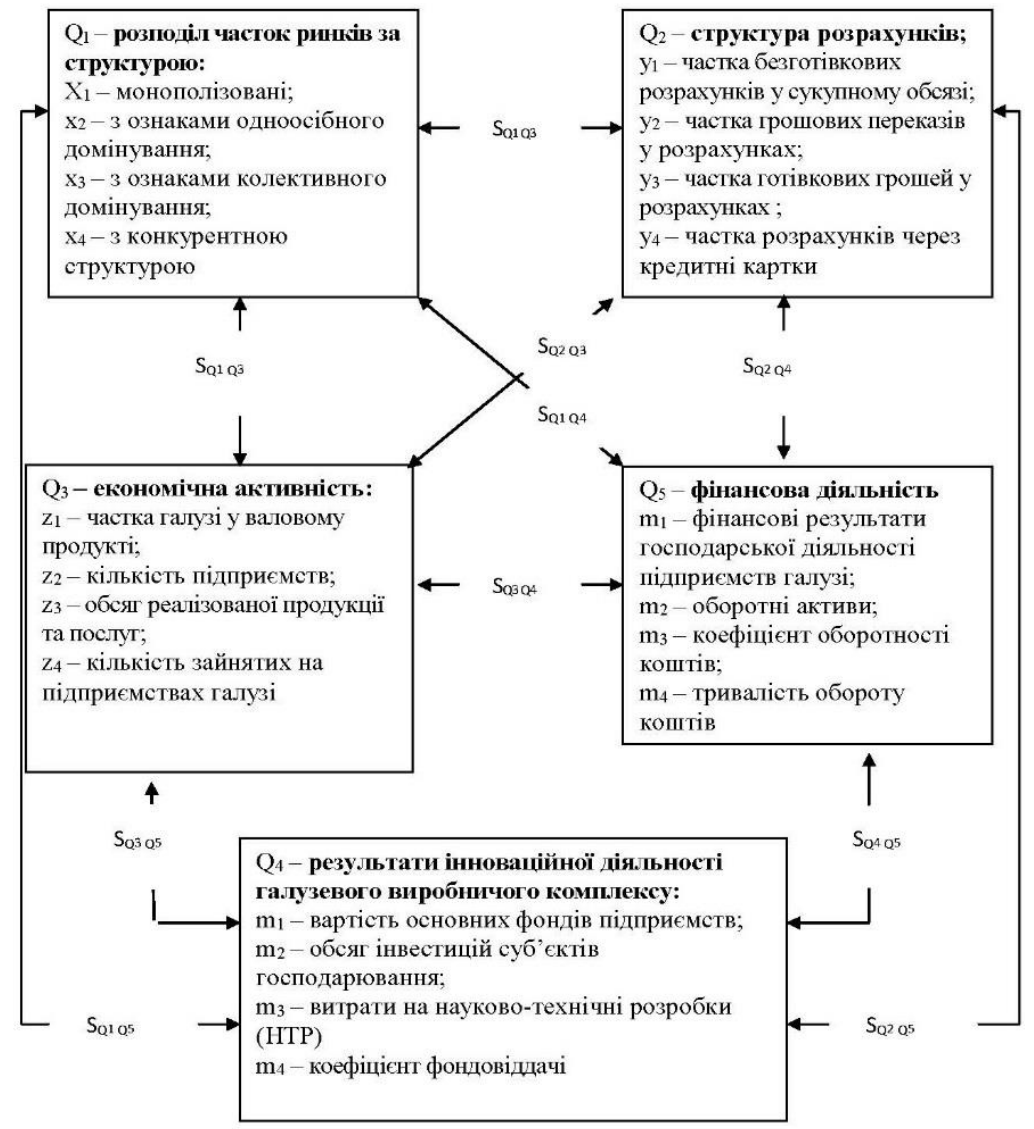

Рисунок 5. Групи детермінант визначення впливу конкурентних параметрів галузевих ринків на використання фінансовоінформаційних технологій безготівкових розрахунків.

Збільшення частки безготівкових розрахунків у платіжному обігу країн $є$ загальносвітовою тенденцією. Проте подальше збільшення безготівкового обороту в Україні повинно грунтуватися на заохоченні всіх учасників цього ринку, а особливо кінцевого споживача. Аналіз засобів платежу та їх споживчих характеристик дозволив виділити переваги та недоліки кожного 3 них та протиставити до готівки (як до найбільш 
розповсюдженого серед населення засобу розрахунків), що в результаті дозволило виділити конкурентні споживчі характеристики кожного засобу платежу. Тому для подальшого стимулювання безготівкових платежів сучасні та майбутні інструменти розрахунків повинні набувати наступних переваг готівкової форми розрахунків: анонімність, безоплатність, розповсюдженість, простота.

Необхідно зазначити, що впровадження цифрового активу вимагає збільшення рівня довіри з боку населення до учасників ринку та інфраструктури безготівкових платежів в цілому. Слід також брати до уваги, що частка використання засобів безготівкових розрахунків у загальному обсязі за торговими операціями буде залежати від стану та розвитку банківської системи і економіки країни, девальваційних та інфляційних очікувань. Переведення заощаджень у безготівкову форму за сучасного стану банківської системи може збільшити ризики їхньої втрати для населення у випадку фінансових криз. 3 огляду на це, актуальними напрямом подальших досліджень стає система адміністративного регулювання та стимулювання безготівкових розрахунків на національному та глобальному рівні. 


\section{ВИСНОВКИ}

Досліджено явище соціально-економічного розвитку. Обгрунтовано особливості соціокультурного контексту, які формують розуміння сутності соціально-економічного розвитку.

Визначено вплив сучасних інформаційних технологій, які істотно змінюють моделі та способи ведення бізнесу.

Досліджено сутність поняття “цифровий актив” на підставі етимологічного аналізу.

Введено в обіг категорію “цифровий актив”, що враховує сутнісно-смислові особливості досліджуваного феномена та характеризується чотирма складовими: економічною, правовою, інформаційною, ціннісною. Це дозволило виокремити особливості використання цього поняття, а також уточнити взаємозв'язок i взаємозалежність між його складовими.

Досліджено сутність прогнозування соціальноекономічного розвитку від впливу цифрового активу в умовах антимонополізації економіки.

Визначено принципи побудови антимонопольного регулювання економіки в умовах цифровізації економіки.

Визначено складові організаційно-методичних засад процесу прогнозування антимонопольного регулювання економіки в умовах цифровізації економіки, а саме: організація діяльності (вивчення та аналіз реального стану антимонопольного регулювання; визначення стратегічних і тактичних цілей); організація умов (нормативно-правове, науково-інформаційне, кадрове, технологічне, матеріально-технічне, фінансове забезпечення); організація моніторингу антимонопольного регулювання; діагностування (готовність до здійснення антимонопольного регулювання, володіння фахівцями методикою антимонопольного регулювання); підготовка до здійснення антимонопольного регулювання; підготовка до вивчення результативності антимонопольного регулювання; моніторинг результативності прогнозу; адаптація результатів та зміна цілей антимонопольного регулювання.

Проаналізовано галузі та особливості їх функціонування за допомогою кластерного аналізу, що дозволить сформувати модель 
конкурентоспроможної та сприятливої для інвестицій економіки, яка спрямована на досягнення високого рівня та якості життя населення.

Обгрунтовано, що дисбаланси та диспропорції, що виникають на фінансовому ринку в результаті впровадження новітніх інформаційних технологій, $є$ проявом i наслідком розбалансованості потреб підтримки цілісності, синхронізації протікання та системної єдності стадій процесу обороту фінансових ресурсів на конкурентних ринках. Для узагальнення характеристик взаємодії різних складових даного процесу за допомогою використання методу побудови канонічних кореляцій визначено характеристики взаємного впливу і залежності між наборами (між двома списками) канонічних змінних, до складу яких було віднесено такі параметри груп детермінант, які за галузевими сегментами визначають впровадження новітніх інформаційних технологій використання цифрових активів у господарських практиках. 


\section{ЛІТЕРАТУРА}

1. Департамент економічної стратегії та макроекономічного прогнозування. Економічний розвиток у розрізі регіонів України. Міністерство розвитку економіки, торгівлі та сільського господарства Украӥни: веб-сайт. URL: https://www.me.gov.ua (Last accessed: 14.01.2020).

2. The treaty on the functioning of the European Union. Official Journal of the European Union. 2012. Vol.55. URL: http://data.europa.eu/eli/treaty/tfeu_2012/oj

doi:10.3000/1977091X.C_2012.326.eng (Last accessed: 14.01.2020).

3. European Commission. Investment for jobs and growth. Promoting development and good governance in EU regions and cities. European Commission: website. URL: http://ec.europa.eu (Last accessed: 17.01.2020).

4. European Commission. Europe 2020. Priorities. European Commission: website. URL: http://ec.europa.eu (Last accessed: 18.01.2020).

5. Commission of the European Communities. Communication from the Commission to the Council and the European Parliament. European Environment Agency: website. URL: https://www.eea.europa.eu (Last accessed: 18.01.2020).

6. European Commission. Connecting Europe Facility. European Commission: website. URL: https://ec.europa.eu (Last accessed: 18.01.2020).

7. Atlantic Council and CEEP. Completing Europe - From the North-South Corridor to Energy, Transportation, and Telecommunications Union. Atlantic Council: website. URL: https://www.atlanticcouncil.org (Last accessed: 20.01.2020).

8. European Commission. Eurostat. European Commission: website. URL: http://ec.europa.eu (Last accessed: 20.01.2020).

9. Аверьянов М., Евтушенко С., Кочетова Е. Цифровая экономика: новые активы. itWeek: веб-сайт. URL: https://www.itweek.ru (дата обращения: 02.02.2020).

10.Арянова Т. Какое будущее ждет цифровые активы. Ihodl Russia: веб-сайт. URL: https://ru.ihodl.com (дата обращения: 02.02.2020). 
11.Сапожков О., Крючкова Е. Цифровые активы двинулись вспять. Коммерсантъ. 2018. № 221. URL: https://www.kommersant.ru (дата обращения: 05.02.2020).

12.Buntinx J. P. Digital assets vs cryptocurrencies. The Merkle: website. URL: https://themerkle.com (Last accessed: 06.02.2020).

13.Fiduciary Access to Digital Assets and Digital Accounts: Act of 12.08.2014 // Delaware Code Online. URL: http://delcode.delaware.gov/title12/c050/index.shtml (Last accessed: 06.02.2020).

14.Gray G. H. New York's Fiduciary Access to Digital Assets Act. Gfrllp: web portal. Last updated: 20.10.2016. URL: http://gfrllp.com/Portals/gfrllp/Documents/NYS-Fiduciary-Access-toDigital-Assets-Gray-Feldman-LLP.pdf (Last accessed: 06.02.2020).

15. Harbinja E. Legal aspects of transmission of digital assets on death: Doctoral dissertation, University of Strathclyde. Glasgow, 2017. URL: $\quad$ http://digitool.lib.strath.ac.uk/R/?func=dbin-jumpfull\&object_id=28644 (Last accessed: 07.02.2020).

16.Kud A., Pypenko I. Social and economic foundation of the implementation of blockchain-based systems of digital assets in developing countries. International Journal of Education and Science. 2018. Vol. 1. No. 3-4. P. 30. doi:10.26697/ijes.2018.3-4.30

17. Have you made a plan for your digital assets? Osterman Law Firm: website. URL: https://www.ostermanlaw.com (Last accessed: 07.02.2020).

18. Walker M. D. The new uniform digital assets law: estate planning and administration in the information age. Real Property, Trust and Estate Law Journal. 2017. № 52 (1). P. 52-78. URL: https://www.americanbar.org/content/dam/aba/publications/real_prope rty_trust_and_estate_law_journal/v52/01/rpte-journal-2017-52-1article-new-uniform-digital-assets-law-estate-planning-andadministration-in-information-age\%20.authcheckdam.pdf (Last accessed: 10.02.2020).

19.Эфириум новости. В чем причина краха ETH? BitStat: веб-сайт. URL: http://bitstat.top (дата обращения: 10.02.2020).

20.Захарова Н. Глава Ripple: “Криптовалюты - это не валюты, а цифровые активы”. BitGit: веб-сайт. URL: https://bitgid.com (дата обращения: 11.02.2020). 
21.Цегоев В. История одной монеты: как биткоин повлиял на мировой финансовый рынок за десять лет своего существования. $\quad R T \quad$ на русском: веб-сайт. URL: https://russian.rt.com (дата обращения: 12.02.2020).

22.Великая Е. Обложат ли виртуальные активы реальными налогами? Delo: веб-портал. Дата обновления: 07.12.2018. URL: https://delo.ua/econonomyandpoliticsinukraine/oblozhat-li-virtualnyeaktivy-realnymi-nalogami-348461 (дата обращения: 12.02.2020).

23.Про внесення змін до Податкового кодексу України щодо оподаткування операцій 3 віртуальними активами в Україні: проект Закону від 27.09.2018 № 9083-1 // Інформ.-правова система “Ліга-Закон"/ВР України.

URL: http://search.ligazakon.ua/1_doc2.nsf/link1/JH70B1AA.html (дата звернення: 15.02.2020).

24.Lenz D. M. Afterlife on the cloud: creating a heavenly plan for electronic assets. Bar Journal. 2012. URL: https://www.sssblaw.com/media/1104/afterlife_on_the_cloud.pdf (Last accessed: 15.02.2020).

25.Owens J. Blockchain 101 for Governments. Vienna: Wilton Park. URL: https://www.wiltonpark.org.uk/wpcontent/uploads/WP1566-Blockchain-101-for-Governments.pdf (Last accessed: 15.02.2020).

26.Latham \& Watkins discusses SEC official's analysis of digital assets as securities/Wink S. P. and others. The CLS Blue Sky Blog: web portal. Last updated: 02.07.2018. URL: http://clsbluesky.law.columbia.edu/2018/07/02/latham-watkinsdiscusses-sec-officials-analysis-of-digital-assets-as-securities/\#_edn4 (Last accessed: 15.02.2020).

27.ДСТУ 3966-2000. Термінологія. Засади і правила розроблення стандартів на терміни та визначення понять. [Чинний від 01.01.2001]. Київ: Держстандарт України, 2000. 36 с.

28.Научно-технический энциклопедический словарь. Академик: веб-сайт. URL: https://dic.academic.ru (дата обращения: 16.02.2020).

29.Ефремова Т. Ф. Новый словарь русского языка. 2-е изд. Москва: Русский язык, 2001. 1084 с. 
30.Финансы. Толковый словарь/общ. ред. И. М. Осадчая. 2е изд. Москва: “Инфра-М”, издательство “Весь Мир”, 2000.

31.Энциклопедический словарь: в 86 т./под ред. И. Е. Андреевского и др. URL: www.vehi.net/brokgauz/ (дата обращения: 16.02.2020).

32.Райзберг Б. А., Лозовский Л. Ш., Стародубцева Е. Б. Современный экономический словарь. 6-е изд., перераб. и доп. Москва: Инфра-М, 2011. 512 с.

33.Ожегов С. И. Толковый словарь русского языка. Москва: Оникс: Biblio, 2010. 736 c.

34.Великий тлумачний словник сучасної української мови (3 дод. і допов.)/уклад. і голов. ред. В. Т. Бусел. Київ; Ірпінь: ВТФ "Перун", 2005. 1728 c.

35.Краткий словарь по кибернетике. Chernykh: веб-сайт. URL: http://chernykh.net (дата обращения: 16.02.2020).

36.Про затвердження Порядку подання та обігу електронних документів державному реєстратору юридичних осіб та фізичних осіб-підприємців: Наказ від 09.02.2016 № 359/5 // База даних “Законодавство України”/M-во юстиції України. URL: https://zakon.rada.gov.ua/laws/show/z0200-16 (дата звернення: 17.02.2020).

37.Про затвердження Порядку проведення електронних аукціонів з розподілення пропускної спроможності міждержавних електричних мереж: Постанова від 28.03.2017 № 426 // База даних “Законодавство України”/Нац. Коміс. України. URL: https://zakon.rada.gov.ua/laws/show/v0426874-17/ed20170328\#n63 (дата звернення: 17.02.2020).

38.Толковый словарь русского языка: в 4 т./под ред. Д. Н. Ушакова. Москва: Терра-Книжный клуб, 2007. Т. 4. 752 с.

39.Додонов В. Н., Ермаков В. Д., Крылова М. А. Большой юридический словарь. Москва: Инфра-М, 2009. 864 с.

40.Матузов Н. И., Малько А. В. Теория государства и права: учебн. 4-е изд., испр. и доп. Москва: Издательский дом “Дело" РаНХиГС, 2015. $528 \mathrm{c}$.

41.Про Національну програму інформатизації: Закон від 01.09.2016 № 74/98-ВР // База даних “Законодавство України”/ВР України.

URL: https://zakon.rada.gov.ua/cgi- 
bin/laws/main.cgi?nreg=74\%2F98-\%E2\%F0 (дата звернення: 17.02.2020).

42.Об информации, информатизации и защите информации: Закон Республики Беларусь от 10.11.2008 № 455-3 // База данных “Белтим СБ”. URL: https://www.beltim.by/wiki/documents/zakonrespubliki-belarus-ob-informatsii-informatizatsii/ (дата обращения: 17.02.2020).

43.Енциклопедія сучасної України: у 20 т. URL: http://esu.com.ua/search_articles.php?id=12472 (дата звернення: 18.02.2020).

44.Долинко В. И. Все об информационнокоммуникационных технологиях и системах связи: учебн. пособ. Москва: Litres, 2018. 59 с.

45.Финансовый словарь. Академик: веб-сайт. URL: https://dic.academic.ru/dic.nsf/fin_enc/23466 (дата обращения: 18.02.2020).

46.Поляков В. П., Косарев В. П. Информатика для экономистов: учебн. Москва: Издательство Юрайт, 2014. 524 с.

47.Шуремов Е. Л. Информационные ресурсы: классификация, источники, поставщики. Коротко о главном. Москва: Издательские решения, 2017. 150 с.

48.Прокопенко А. Н. О содержании понятия информационные ресурсы в праве. Бизнес в законе. 2010. № 1. C. $157-160$.

49.Информационные ресурсы развития Российской Федерации: Правовые проблемы/отв. ред. И. Л. Бачило. Москва: Наука, 2003. 402 с.

50.Финансово-инвестиционный толковый словарь. Академик: веб-сайт. URL: https://dic.academic.ru (дата обращения: 18.02.2020).

51.Финансовый словарь. Академик: веб-сайт. URL: https://dic.academic.ru/dic.nsf/fin_enc/26068 (дата обращения: 18.02.2020).

52.Уолпорт М. Технология распределенного реестра: за рамками блокчейн. Plus: веб-сайт. URL: https://www.plusworld.ru (дата обращения: 19.02.2020). 
53.Применение технологии распределенного реестра для построения защищенного документооборота/Заворина Л. Д. и др. Известия Тульского государственного университета. 2018. Вып. 10. С. 3-7.

54.Савельев А. Юридическая дефиниция блокчейна. Zakon: веб-портал. Дата обновления: 30.10.2017. URL: https://zakon.ru/blog/2017/10/30/chast_2_yuridicheskaya_definiciya_ blokchejna_a_tochnee_-_raspredelennogo_reestra_dannyh (дата обращения: 19.02.2020).

55.Бизнес. Толковый словарь/общ. ред. И. М. Осадчая. Москва: “Инфра-М”, издательство “Весь Мир”, 1998.

56.Энциклопедический словарь. Tolkslovar: веб-сайт. URL: http://tolkslovar.ru (дата обращения: 19.02.2020).

57.Грабовецький Б. С. Планування та економічне прогнозування : навчальний посібник. Вінниця : ВНТУ, 2013. 66 с.

58.Стельмащук А. М. Державне регулювання економіки. Тернопіль: ТАНГ, 2000. 315 с.

59.Швайка Л. А. Державне регулювання економіки. Київ: Знання, 2006. 435 c.

60.Дикань Н. В., Борисенко I. I. Менеджмент: навч. посіб. для студентів, аспірантів, викладачів ВНЗ. Київ, 2008. 389 с.

61.Наджафов 3., Гусейнова А. Новая экономика XXI века или цифровизация экономики? Побудова інформаційного суспільства: ресурси і технології: матеріали XVIII Міжнародної наук.-практ. конф., 19-20 верес. 2019 р. Київ: УкрIHTЕI, 2019. C. 52-59.

62. Єгоров I., Рижкова Ю. Соціально-економічні аспекти процесів цифровізації: інструменти дослідження у країнах ОЕСР. Побудова інформачійного суспільства: ресурси $i$ технологї̈: матеріали XVIII Міжнародної наук.-практ. конф., 19-20 верес. 2019 р. Київ: УкрIHТЕI, 2019. С. 9-12.

63.Кленін О.В. основні тренди цифрової трансформації держави та бізнесу. Побудова інформаційного суспільства: ресурси і технології: матеріали XVIII Міжнародної наук.-практ. конф., 19-20 верес. 2019 р. Київ: УкрIНТЕI, 2019. С. 44-47. 
64.The digital economy and society index (DESI). European Commission: website. URL: https://ec.europa.eu (Last accessed: 15.02.2020).

65.World payments report 2014: Report of Capgemini and The Royal Bank of Scotland. Capgemini: website. URL: https://www.capgemini.com (Last accessed: 15.02.2020).

66.Ринок карткових платежів України: міжнародний досвід та національне регулювання. Аналітичний звіт. Київ: АДЕФУкраїна, 2012. 60 с.

67.Бублик Є. О. Обмеження готівкових розрахунків в Україні: проблеми та перспективи. Економіка і прогнозування. 2013. № 2. C. 32-42.

68.Лист 02/03-2014 НБУ від 15.04.2014 [додаток 1]: Українська міжбанківська асоціація членів платіжних систем. 2014.

URL: http://ema.com.ua/wpcontent/uploads/2014/05/strategy_development_ improvement_payments.pdf (дата звернення: 17.02.2020).

69.Кочергин Д. А. Электронные деньги. Санкт-Петербург: Маркет ДС, 2011. 424 c.

70.Ткачук А. В. Перспективы распространения безналичных розничных платежем. Деньги и кредит. 2012. № 7. С. 24-32.

71.Річний звіт Національного банку України за 2013 рік: затв. рішенням Ради Національного Банку України від 24.04.2014 p. № 13. URL: http://www.bank.gov.ua/doccatalog/document?id=8253030 (дата звернення: 17.02.2020). 
Науково-виробниче видання

Прогнозування впливу цифрових активів на соціально-економічний розвиток підприємства

Методичний посібник

\section{КУДЬ Александр Александрович \\ МАЩЕНКО Марина Анатоліївна ПИПЕНКО Ірина Сергї̈вна СОБОЛЕВА Ірина Володимирівна}

ISBN 978-617-7089-09-3

DOI 10.26697/9786177089093.2020

Видасться в авторській редакції

Відповідальний випусковий: Ю. Б. Мельник

Комп'ютерне складання та верстання: Я. Ю. Свячена

Формат 80х641\%

Гарн. «Тіmes». Папір для мн. ап. Друк цифровий.

Ум. друк. арк. 4,5. Зам. № 1-27.

Тираж 300 пр.

Харківський національний економічний університет імені С. Кузнеця Україна, 61166, м. Харків, пр. Науки, 9-а

Харківська обласна громадська організація “Культура Здоров'я"

Україна, 61105, м. Харків, пров. Забайкальський, 6/6. http://publisher.culturehealth.org; тел./факс: (057)775-75-23.

Emails: CultureHealth@ukr.net; KOSOCH@gmail.com;

Свідоцтво про державну реєстрацію видавництва ДК № 4387 від 10.08.2012 